\title{
IMPACTOS DO FUNDO CONSTITUCIONAL DE FINANCIAMENTO DO NORTE: EVIDÊNCIAS DO ESTIMADOR DE DIFERENÇAS EM DIFERENÇAS ${ }^{1}$
}

\author{
Lindomar Pegorini Daniel² \\ Marcelo José Braga ${ }^{3}$
}

\begin{abstract}
Esse estudo analisa o impacto econômico promovido pelo acesso ao crédito concedido às empresas da região Norte no período 2000-2010 por meio do Fundo Constitucional de Financiamento do Norte (FNO). Para avaliar a presença de impactos sobre emprego, massa salarial e salário médio utiliza-se o procedimento de diferenças em diferenças, que apresenta controle para heterogeneidade não observável e a possibilidade de testar a causalidade entre o tratamento e o impacto promovido. Os resultados variam de acordo com o setor de atividade e com o porte das empresas, mas, em média, ter acesso ao crédito subsidiado eleva em cerca de $20 \%$ e $13 \%$ a geração de emprego e a massa salarial no curto prazo para empresas que financiam capital de giro e custeio e para as que financiam investimento, respectivamente. No longo prazo, o impacto gira em torno de $28 \%$ e $15 \%$. Já para o salário médio não foram identificados impactos significativos.
\end{abstract}

Palavras-chave: avaliação de impacto; diferenças em diferenças; FNO.

\section{IMPACTS OF NORTH CONSTITUTIONAL REGIONAL FUND (FNO): A DIFFERENCES-IN-DIFFERENCES APPROACH}

We aimed to analyze the economic impact related to the access of credit granted by North Constitutional Regional Fund (FNO) to enterprises on North region of Brazil in the 2000 to 2010 period. To evaluate the presence of economic impacts on employment, total wage bill and average wage when firms have access to credit at special rates we use the differences in differences impact evaluation procedure that have control under unobservable heterogeneity and the possibility to test the causality between treatment and economic impact. Results differ according to the sector of activity and the size of the firms, but on average the access to subsidized credit increases by $20 \%$ and $13 \%$ the generation of employment and total wage bill in the short term for companies that finance working capital and for financing investment, respectively. In long run, the impact is around $28 \%$ and $15 \%$. As for the average wage were not identified significant economic impacts.

Keywords: impact evaluation; differences in differences; FNO.

\section{IMPACTOS DEL FONDO CONSTITUCIONAL DE FINANCIACIÓN DEL NORTE (FNO): EVIDENCIAS DEL ESTIMADOR DE DIFERENCIAS EN DIFERENCIAS}

Este estudio analiza el impacto económico promovido por el acceso al crédito concedido a las empresas de la región Norte de Brasil en el período de 2000 a 2010 a través del Fondo

1. DOI: http://dx.doi.org/10.38116/ppp55art4

2. Professor adjunto da Universidade do Estado de Mato Grosso - Campus de Sinop. (Unemat). E-mail: <lindomar. pegorini@unemat.br>.

3. Professor do Departamento de Economia Rural da Universidade Federal de Viçosa (DER/UFV).E-mail:<mjbraga@ufv.br>. 
Constitucional de Financiamiento del Norte (FNO). Para evaluar la presencia de impactos sobre empleo, masa salarial y salario medio se utiliza el procedimiento de diferencias en diferencias que presenta control de heterogeneidad no observable y la posibilidad de probar la causalidad entre el proceso, tratamiento y el impacto promovido. Los resultados varían de acuerdo con el sector de actividad y con el porte de las empresas, pero, en promedio, tener acceso al crédito subsidiado eleva en cerca de $20 \%$ y $13 \%$ la generación de empleo y la masa salarial a corto plazo para empresas que financian capital de giro y costeo y para las que financian inversión, respectivamente. A largo plazo, el impacto gira en torno al $28 \%$ y el $15 \%$. Ya para el salario medio no se identificaron impactos significativos.

Palabras clave: evaluación de impacto; diferencias en diferencias; FNO.

\section{IMPACTS DU FONDS CONSTITUTIONNEL DU FONDS NORD (FNO): PREUVE DE L'ESTIMATEUR DES DIFFERENCES DE DIFFERENCES}

Cette étude analyse l'impact économique de l'accès au crédit accordé aux entreprises du nord du Brésil entre 2000 et 2010 par le biais du Fonds de financement constitutionnel du Nord (FNO). Afin d'évaluer la présence d'impacts sur l'emploi, la masse salariale et le salaire moyen est utilisé, il différences des différences de procédure que le contrôle de l'hétérogénéité inobservable et la possibilité de tester la causalité entre traitement et impact. Les résultats varient selon le secteur d'activité et la taille des entreprises, mais en moyenne ont accès à des augmentations de crédit subventionnées par environ $20 \%$ et $13 \%$ la création d'emplois et de la masse salariale à court terme pour les entreprises qui financent le capital et les fonds d'investissement, respectivement. À long terme, l'impact est d'environ $28 \%$ et $15 \%$. Pour le salaire moyen, aucun impact significatif n'a été identifié.

Mots-clés: évaluation d'impact; différences dans les différences; FNO.

JEL: C23; D22.

\section{INTRODUÇÃO}

Com o objetivo de dirimir as desigualdades regionais no Brasil, por meio de maior acesso ao crédito, foram criados em 1988 o Fundo Constitucional de Financiamento do Norte (FNO), o Fundo Constitucional de Financiamento do Centro-Oeste (FCO) e o Fundo Constitucional de Financiamento do Nordeste (FNE). Para a constituição dos fundos, são destinados, anualmente, $3 \%$ da arrecadação do Imposto de Renda (IR) e do Imposto sobre Produtos Industrializados (IPI). A distribuição foi definida em: 0,6\% para FNO e FCO e os 1,8\% restantes para o FNE. Esses recursos são aplicados pelo Banco da Amazônia - Basa (FNO), pelo Banco do Brasil BB (FCO) e pelo Banco do Nordeste - BNB (FNE), entre outras instituiçôes, em programas de financiamento com taxas subsidiadas aos setores produtivos. Os limites de valor dos empréstimos, bem como seus encargos financeiros, são determinados pelo porte do tomador, pela natureza da linha de crédito (aquisição de insumos de curto ou longo prazo) e tipo do programa de financiamento. 
Conforme destaca o Basa (2012), o FNO é o principal instrumento econômico-financeiro para o desenvolvimento econômico da região Norte. O FNO atua alinhado às demais políticas do governo federal orientadas ao desenvolvimento da região Norte. Torna-se, então, necessário investigar se o relaxamento da restrição de crédito ao setor produtivo tem resultado no aumento da produtividade e em novos postos de trabalho na região Norte. Adicionalmente, é importante buscar evidências de que os resultados possam ser atribuídos à intervenção do programa, ou seja, deve-se identificar a existência de uma relação de causalidade entre os recursos injetados na economia da regiáo pelo programa e os ganhos econômicos.

O simples fato dos recursos provenientes dos fundos serem de origem pública justificaria uma avaliação de impacto, pois esse é um processo ainda incipiente no Brasil como apontam Silva, Resende e Silveira Neto (2009). Entretanto, a literatura tem apresentado resultados controversos, tornando difícil apontar uma conclusão definitiva sobre a importância e a eficácia das políticas vinculadas aos fundos constitucionais de financiamento. Com relação à política pública de crédito subsidiado vinculada aos fundos constitucionais de financiamento, Oliveira e Domingues (2005), Silva, Resende e Silveira Neto (2006; 2009), Almeida Júnior, Resende e Silva (2007), Funarbe (2012a; 2012b), Braga et al. (2012), Resende (2014a; 2014b), Resende, Cravo e Pires (2014), Oliveira, Menezes e Resende (2015) e Resende, Silva e Silva Filho (2015) avaliam os impactos dos recursos empenhados.

Oliveira e Domingues (2005) avaliam o impacto dos recursos aplicados pelo FCO e FNO sobre o crescimento da renda per capita para os anos de 1991 e 2000 nos municípios das regióes Centro-Oeste e Norte, respectivamente. Como resultado não se observou impacto dos fundos sobre o crescimento da renda per capita.

Silva, Resende e Silveira Neto (2006) conduzem a análise de eficácia para a aplicação de recursos do FNE e do FNO sobre a taxa de variação do salário médio pago pelas firmas e sobre a taxa de variação do número de empregados. Aplica-se o método de escore de propensão com pareamento, do inglês propensity score matching (PSM) para a análise sobre empresas beneficiadas e não beneficiadas para o setor formal da economia entre 1995 a 1998 para o FNE e entre 2000 a 2003 para o FNO. Para os períodos destacados, não foi possível identificar qualquer impacto do FNE e FNO sobre a taxa de variação dos salários médios pagos pelas firmas; no entanto, se verificou impacto positivo nos dois casos em relação à taxa de variação do número de empregados. De forma geral, o FNE elevou a taxa de variação do número de empregados entre 65,5 e 67,7 pontos percentuais (p.p.) em relação ao cenário em que não houvesse o programa, já o FNO elevou em torno de 32 p.p.

Já Almeida Júnior, Resende e Silva (2007) procuram verificar se os recursos do FNE, FNO e FCO têm sido distribuídos de acordo com os objetivos de redução de desigualdades intrarregionais. Em outras palavras, os autores tentam identificar 
se existe concentração de concessão desses recursos em municípios mais pobres. Como resultado observa-se que a alocação desses recursos está concentrada em municípios mais ricos com economia mais dinâmica, o que evidenciaria que esse objetivo náo estaria sendo cumprido.

Silva, Resende e Silveira Neto (2009) também avaliam a eficácia dos fundos constitucionais FNE, FNO e FCO para o período 2000-2003. Utilizando o método PSM, os autores avaliam a variação da taxa do número de empregos e de salários médios pagos pelas firmas beneficiárias e não beneficiárias para o setor formal da economia. Entre os resultados, para a taxa de variação do número de empregos é possível verificar uma diferença positiva de 55,7 p.p., em média, em relação às beneficiadas e não beneficiadas para o Nordeste; contudo, não há evidências de impactos de qualquer natureza para o Norte e Centro-Oeste. Já para a taxa de variação do salário médio pago, náo é possível encontrar impactos em nenhuma das regióes. Em estudos específicos para o FNO, Funarbe (2012a) avaliou os impactos dos recursos aplicados do FNO sobre a economia dos estados da região Norte. Utilizando os modelos de insumo-produto, ano-base 2008, e de equilíbrio geral para o período 2000-2010. A análise conclui que o FNO tem sido bom instrumento indutor do desenvolvimento regional. Segundo o estudo, o programa gerou aumento na produção, renda e salários, no entanto, não tem reduzido os desequilíbrios regionais. Ainda, Funarbe (2012b) mensura o índice da produtividade total dos fatores (PTF) para os estados da regiáo Norte para o período 1995- 2009 a partir da utilização do modelo de crescimento exógeno e do modelo ampliado pelo capital humano. Posteriormente, avaliou-se o efeito dos diversos fatores sobre o índice da PTF, entre eles o montante de recursos do FNO. Entre os resultados observados destaca-se que os recursos do FNO destinados aos estados da regiâo Norte apresentaram correlação positiva para com a PTF.

Braga et al. (2012), também utilizando o método PSM e o setor formal da economia da regiáo Norte, investiga os impactos econômicos do FNO sobre o estoque de emprego, a massa de salários e os salários médios para o período 2000-2010. Os resultados apontam para ausência de impacto significativo sobre o estoque de emprego; contudo, verifica-se impacto positivo em relação a massa salarial e salários médios. Os resultados variam de acordo com o setor e o tamanho das empresas.

Resende (2014a; 2014b) e Resende, Cravo e Pires (2014) utilizam modelos para dados em painel para avaliar o impacto econômico do FNE, do FNO e do FCO, respectivamente, sobre a renda per capita municipal para o período 20042010 para diferentes níveis geográficos. Para o FNE, verifica-se impacto positivo sobre a renda per capita em níveis municipal e regional devidos, em grande parte, ao crédito concedido ao setor agropecuário. Para o FNO, apesar de resultados setoriais positivos, de forma geral, são encontrados impactos negativos sobre o 
crescimento da renda per capita municipal. Já para o FCO, evidencia-se impacto positivo sobre a renda per capita apenas para o nível municipal e, em grande parte, devido à modalidade empresarial de empréstimos.

Oliveira, Menezes e Resende (2015) argumentam que são os primeiros a analisarem as funções dose-resposta para a aplicação de fundos regionais e, ao tratarem da aplicação do FCO em Goiás, os autores encontram impactos positivos no período 2004-2011 para todos os valores considerados, contudo, valores até R\$ 50 mil apresentam maior impacto relacionado aos demais níveis de crédito.

Sob a ótica da tipologia da Política Nacional de Desenvolvimento Regional (PNDR), Resende, Silva e Silva Filho (2015) utilizam modelos de econometria espacial para dados em painel para avaliar o impacto dos fundos constitucionais (FNE, FNO e FCO) sobre o crescimento do produto interno bruto (PIB) per capita municipal entre 1999 e 2011 nos municípios e microrregióes abrangidas. Os resultados apontam, para o FNE, que municípios e microrregióes tipificadas como dinâmicas e de baixa renda evidenciam impactos positivos. Já para o FNO, impactos positivos são encontrados para municípios caracterizados como dinâmicos e de alta renda. Por fim, impactos positivos também foram encontrados para o FCO em municípios e microrregióes classificadas como de alta renda.

Apesar da literatura já existente sobre a avaliação das políticas que visam o relaxamento da restriçâo de crédito vinculado aos fundos constitucionais, especialmente ao $\mathrm{FNO}$, os resultados encontrados são divergentes e fornecem evidências para efeitos positivos, nulos e até mesmo negativos. Parte da divergência dos resultados pode ser atribuída, entre outros fatores, aos diferentes recortes da amostra, às variáveis e aos métodos analíticos utilizados. Além disso, o FNO define que o motor dos impactos do programa deve ser o aumento de produtividade, mas náo especifica sobre quais variáveis ou medidas devem-se observar os impactos do programa. Para lidar com as dificuldades de amostragem, o presente artigo adota as firmas como unidades a serem observadas, a partir de bases de dados sigilosas cedidas pelo Basa e pelo Ministério do Trabalho e Emprego (MTE).

Em relação aos métodos analíticos, a literatura não considera eventos que possam distorcer as análises. Em nível de firmas, ao mensurar o impacto sobre a massa salarial, o estoque de emprego e o salário médio, os trabalhos utilizam-se do PSM; contudo, esse método possui pressuposiçôes fortes, como a de que fatores não observados não afetam a decisão de participação ao tratamento e a necessidade de existência de uma região de suporte comum de propensão a participar do tratamento entre os grupos tratados e de controle (Gertler et al., 2011). Caso os fatores não observados sejam relevantes, as estimativas pelo método PSM apresentarão problemas de simultaneidade e efeitos de equilíbrio geral, os quais causam problemas de viés de seleção, uma vez que afetariam a decisão de tomar crédito. 
Nesse caso, o estimador de diferenças em diferenças (DD) apresenta-se como mais adequado, como sugerido por Khandker, Koolwal e Samad (2009) e Gertler et al. (2011). Ao utilizar o arcabouço analítico dos dados em painel, é possível controlar explicitamente a heterogeneidade não observável e invariante no tempo através dos efeitos fixos, controlando a simultaneidade e os efeitos de equilíbrio geral (dinâmica) presentes na decisão de participar do programa (Imbens e Wooldridge, 2009). Além disso, o método permite o controle da heterogeneidade observável e variável no tempo sem a necessidade de uma região de suporte comum de propensão a participar do grupo tratado. Ainda, o método DD permite testar a causalidade entre o tratamento e o impacto promovido a partir dos testes de robustez (Imbens e Wooldridge, 2009; Gertler et al., 2011). Por esses motivos, o método DD apresenta maior consistência em relaçáo aos tradicionalmente utilizados pela literatura apresentada.

O presente artigo contribui, nesse sentido, ao apresentar novas evidências acerca dos impactos promovidos pelos fundos constitucionais de financiamento, corroborando os demais trabalhos até agora desenvolvidos para a avaliaçáo dos impactos do FNO sobre o relaxamento das restriçôes de crédito. Além disso, os resultados são desagregados por porte e grande setor de atividade e são avaliados os efeitos iniciais e contínuos (no curto e longo prazo) do programa, uma vez que tão importante quanto saber se existem ou não impactos é conhecer sua magnitude e seu comportamento ao longo do tempo. Portanto, o objetivo desta pesquisa é apresentar evidências a partir do estimador DD sobre os impactos ex-post do programa de intervenção de crédito subsidiado vinculado ao FNO sobre as firmas de diferentes portes e setores da região Norte no período 2000- 2010.

Além desta introdução, o artigo está organizado em mais quatro seçôes. A seção 2 apresenta os aspectos teóricos. A seçáo 3 traz o modelo empírico aplicado para avaliar o impacto do FNO sobre o estoque de emprego, a massa salarial e o salário médio. A seção 4 apresenta os resultados e a discussão do estudo. A seção 5 faz as consideraçóes finais.

\section{ASPECTOS TEÓRICOS}

O referencial teórico utilizado nesta pesquisa baseia-se na modelagem da decisão microeconômica de maximizaçáo de lucros das firmas na presença de restriçôes de crédito. Esta seção fornecerá parâmetros para a mensuração do impacto do FNO como mecanismo de relaxamento das restriçóes de crédito em nível de firmas.

A princípio, identificam-se na literatura três abordagens como sendo as principais ao se tratar do efeito das restriçôes de crédito sobre o comportamento das firmas. A primeira, e mais comum, utiliza modelos de maximizaçáo de lucros para explicar o comportamento das firmas na presença de restriçáo de liquidez, exemplos dessa abordagem podem ser encontrados em Lee e Chambers (1986), Färe, Grosskopf e Lee (1990), Blancard et al. (2006) e Ciaian, Fałkowski e Kancs (2012). 
A segunda abordagem parte de modelos de investimento baseados no teorema de Modigliani e Miller (1958), que afirmam que as decisóes de investimento das firmas seriam independentes das decisóes de financiamento. Essa linha de estudos investiga como os resultados das firmas são afetados quando o teorema é violado, uma aplicação dessa abordagem é feita por Mishra, Moss e Erickson (2008). Por fim, a terceira abordagem faz uso de modelos de informação assimétrica. Nesse caso, o risco e a assimetria de informação no mercado financeiro podem levar ao risco moral e à seleção adversa, fazendo com que o acesso ao crédito se torne mais restrito, impactando no comportamento das firmas. Guirkinger e Boucher (2008) fazem uso desse arcabouço teórico.

A abordagem a ser adotada pelo presente artigo baseia-se nos modelos de maximização de lucro com restrição de crédito assimétrica desenvolvida por Blancard et al. (2006) e Ciaian, Fałkowski e Kancs (2012), uma vez que o interesse reside no impacto econômico ex-post promovido pelo relaxamento das restriçóes de crédito, ou seja, após a firma ter obtido acesso ao crédito no qual a "decisão de investimento" já foi tomada e as imperfeiçóes do mercado de crédito não impediram o acesso ao crédito.

\subsection{0 modelo de restrição de crédito assimétrica}

O arcabouço teórico utilizado nessa seção é baseado nos modelos de Blancard et al. (2006) e Ciaian, Fałkowski e Kancs (2012). Trata se de um modelo neoclássico de maximização de lucros de uma firma representativa sujeita a restrição de liquidez para a aquisição de insumos. Nesse modelo, assume-se que a firma representativa possui uma função (tecnologia) de produção com retornos constantes à escala $(f(X, Y))$ que depende de dois insumos, $X$ e $Y$. O lucro é dado por $\Pi=p f(X, Y)-w_{X} X-w_{Y} Y$, em que $p$ é o preço do produto e $w_{i}$ é o preço dos insumos para $i=X, Y$.

Segundo Blancard et al. (2006) e Ciaian, Fałkowski e Kancs (2012), a imperfeiçáo no mercado de crédito é inserida no modelo ao assumir que as firmas enfrentam restrição de liquidez. A firma representativa possui montante $C$ disponível para o financiamento da aquisição de insumos. $\mathrm{O}$ valor de crédito $C$ é predeterminado e não pode ser excedido na aquisiçẫo de insumos:

$$
\alpha w_{X} X+\delta w_{Y} Y \leq C
$$

em que $\alpha$ e $\delta$ são variáveis binárias que distinguem a restrição de crédito da firma entre os insumos. Se $\alpha=1$ e $\delta=1$, então implica que a restrição de crédito é simétrica, ou seja, é a mesma para ambos os insumos. Entretanto, determinada firma pode ter restrição de crédito maior em algum insumo quando comparado a outros, implicando restriçóes de crédito assimétricas. Em outras palavras, a firma pode ter mais dificuldade financeira em adquirir certos insumos necessários à sua produção, o que pode levar a adoção de tecnologias menos produtivas. Por simplicidade, assume-se que a firma enfrenta restrição de crédito com respeito a um insumo apenas, $X(\alpha=1$ e $\delta=0)$ ou $Y(\alpha=0$ e $\delta=1)$. 
A firma maximiza lucros estando sujeita a restrição de crédito (1) de acordo com o seguinte Lagrangeano:

$$
L=p f(X, Y)-w_{X} X-w_{Y} Y-\lambda\left(\alpha w_{X} X+\delta w_{Y} Y-C\right),
$$

em que $\lambda$ é o preço sombra da restrição de crédito. As condições para a maximização de lucro de uma firma sujeita a restrição de crédito são as seguintes:

$$
\begin{aligned}
& p f_{X}=(1+\lambda \alpha) w_{X} \\
& p f_{Y}=(1+\lambda \delta) w_{Y} .
\end{aligned}
$$

Das equaçóes (3) e (4) segue que se, por um lado, a firma possui restrição de crédito simétrica, o valor do produto marginal de ambos os insumos é maior do que seus preços no equilíbrio, ou seja, se $\alpha=1, \delta=1$ e $\lambda>0$ então $p f_{X}>w_{X}$ e $p f_{Y}>w_{Y}$, respectivamente. Isso significa que a firma poderia aumentar seus lucros aumentando a produção e, consequentemente, o uso de insumos. No entanto, isso não é possível devido à restrição de crédito. Por outro lado, caso a firma possua restrição de crédito assimétrica em $X(\alpha=1, \delta=0$ e $\lambda>0)$, então, apenas o valor do produto marginal de $X$ excede seu preço, enquanto o valor do produto marginal de $Y$ é igual a seu preço: $p f_{X}>w_{X}$ e $p f_{Y}=w_{Y}$, respectivamente. $\mathrm{O}$ oposto é válido caso a firma possua restrição de crédito assimétrica em $Y(\alpha=0, \delta=1$ e $\lambda>0)$, então: $p f_{X}=w_{X}$ e $p f_{Y}>w_{Y}$. Por fim, se a restrição de crédito (1) da firma não limitar o uso de insumos $(\lambda=0)$, então o valor do produto marginal de ambos os insumos é igual ao seu respectivo preço: $p f_{X}=w_{X}$ e $p f_{Y}=w_{Y}$.

A restrição de crédito, quando assimétrica, limita o uso de um insumo: a firma enfrenta restrição de crédito com respeito a $X(\alpha=1$ e $\delta=0)$ ou $Y(\alpha=0$ e $\delta=1)$. Considere uma redução no montante de crédito disponível de $C$ para $C_{1}\left(C_{1}<\right.$ $C)$, em que $C_{1}$ faz com que a restrição de crédito (1) limite o comportamento da firma $\left(\lambda_{1}>0\right)$. $\mathrm{O}$ montante de crédito $C_{1}$ afeta uma das condiçóes de equilíbrio da firma (3) ou (4), dependendo em qual dos insumos ela enfrenta restriçóes de liquidez. A restrição de crédito assimétrica aumenta o valor do produto marginal do insumo restrito acima de seu preço de mercado, enquanto a igualdade para o insumo não restrito permanece inalterada: $p f_{i}\left(C_{1}\right)-\left.w_{i}\right|_{A S}>p f_{j}\left(C_{1}\right)-\left.w_{j}\right|_{A S}=0,{ }^{4}$ para $i, j=X, Y$ - seguindo as equaçóes (3) e (4) -, em que assume-se que o insumo $i$ é restrito em relação ao crédito.

O impacto da restrição de crédito assimétrica pode ser decomposto em dois efeitos: efeito escala e efeito substituiçáo. Como exemplo, considere o caso em que

4. As notações $\left.\left.x\right|_{*,} x\right|_{S}$ e $\left.x\right|_{A S}$ definem situações de equilíbrio sem restrições de crédito, com restrições de crédito simétricas e com restrições de crédito assimétricas, respectivamente. 
a firma enfrenta restrição de crédito sobre o insumo $X(\alpha=1$ e $\delta=0)$. Comparada à situação sem restrição de crédito, a diminuição no volume de liquidez disponível provoca redução na escala de produção. Isso implica menor nível de produto quando a firma enfrenta restrição de crédito assimétrica em comparação à situação em que não há restrição de crédito. A escala reduzida de produto também diminui o uso de ambos os insumos $\left(X_{A S}<X^{*}\right.$ e $\left.Y_{A S}<Y^{*}\right)$.

Quanto ao efeito substituição, as equaçóes (3) e (4) implicam:

$$
\left.\frac{p f_{i}(C)}{p f_{j}(C)}\right|_{*}=\left.\frac{w_{i}}{w_{j}}\right|_{*}<\left.\frac{p f_{i}\left(C_{1}\right)}{p f_{j}\left(C_{1}\right)}\right|_{A S}=\left.\left(1+\lambda_{1}\right) \frac{w_{i}}{w_{j}}\right|_{A S} \text {, }
$$

em que o insumo $i$ é restrito com relação ao crédito. Como resultado, a restrição de crédito assimétrica altera o valor do produto marginal relativo dos insumos pelo valor do preço sombra do insumo restrito $\lambda_{1}$. Em resposta, a firma substitui o insumo restrito pelo irrestrito, pois $p f_{i}(C) /\left.p f_{j}(C)\right|_{*}<p f_{i}\left(C_{1}\right) /\left.p f_{j}\left(C_{1}\right)\right|_{A s}$. Portanto, o efeito substituição muda a quantidade relativa de insumos para dado nível de produto. $\mathrm{O}$ uso do insumo restrito $X$ decresce, enquanto a quantidade do insumo irrestrito $Y$ aumenta. Do que segue, em relação ao insumo restrito $X$, o efeito substituição (redução) ocorre na mesma direção que o efeito escala (redução). O oposto é válido para o insumo irrestrito $Y$, que o efeito escala provoca redução e o efeito substituição acréscimo.

Em suma, restriçôes de crédito assimétricas reduzem o produto de equilíbrio, diminuem o uso do insumo restrito e podem reduzir ou aumentar o uso do insumo irrestrito dependendo da força de cada efeito, escala e substituição. As firmas expandem o uso do insumo irrestrito se o efeito substituição for maior que o efeito escala. Para o caso inverso, se o efeito substituição for menor que o efeito escala, entấo a firma também reduz o uso do insumo irrestrito, em relação à situação na qual não há restrição de crédito.

De outra forma, com restrição de crédito simétrica $(\alpha=1, \delta=1)$, a firma enfrenta a mesma restrição de crédito com respeito a ambos os insumos. Diferenciando totalmente as condiçóes de maximização de lucro (3) e (4) e a restrição de crédito (1), e resolvendo para $d X /\left.d C\right|_{S}, d Y /\left.d C\right|_{S}$ e $d f /\left.d C\right|_{S}$ tem-se:

$$
\begin{aligned}
& \left.\frac{d X}{d C}\right|_{S}=\frac{\left(1 / w_{X}\right)\left(p f_{Y Y}-p f_{Y Y}\left(\delta w_{Y} / w_{X}\right)\right)}{p f_{Y Y}+\left(p f_{X X}\left(\delta w_{Y} / w_{X}\right)-p f_{Y X}-p f_{X Y}\right)\left(\delta w_{Y} / w_{X}\right)}>0 . \\
& \left.\frac{d Y}{d C}\right|_{S}=\frac{\left(1 / w_{X}\right)\left(p f_{X X}\left(\delta w_{Y} / w_{X}\right)-p f_{Y X}\right)}{p f_{Y Y}+\left(p f_{X X}\left(\delta w_{Y} / w_{X}\right)-p f_{Y X}-p f_{X Y}\right)\left(\delta w_{Y} / w_{X}\right)}>0 .
\end{aligned}
$$




$$
\left.\frac{d f}{d C}\right|_{S}=\frac{f_{Y}\left[p f_{X X}\left(\delta w_{Y} / w_{X}\right)-p f_{Y X}\right]+f_{X}\left[p f_{Y Y}-p f_{X Y}\left(\delta w_{Y} / w_{X}\right)\right]}{w_{X}\left[p f_{Y Y}+\left(p f_{X X}\left(\delta w_{Y} / w_{X}\right)-p f_{Y X}-p f_{X Y}\right)\left(\delta w_{Y} / w_{X}\right)\right]}>0 .
$$

A restrição de crédito simétrica reduz tanto o uso de insumos quanto o nível de produto. Considere uma redução no crédito disponível de $C$ para $C_{2}\left(C_{2}<C_{1}\right.$ $<C$ ), a restrição de crédito simétrica não afeta o produto marginal relativo:

$$
p f_{i}(C) /\left.p f_{j}(C)\right|_{*}=w_{i} /\left.w_{j}\right|_{*}=p f_{i}\left(C_{2}\right) /\left.p f_{j}\left(C_{2}\right)\right|_{S}=\left(1+\lambda_{2}\right) w_{i} /\left.\left(1+\lambda_{2}\right) w_{j}\right|_{S}=w_{i} /\left.w_{j}\right|_{S} .
$$

Como resultado, o efeito substituição não ocorre. Apenas o efeito escala irá reduzir o uso de insumos e o nível de produção da firma. Comparada à situação em que não há restriçẫo de crédito, a firma usará menos de ambos os insumos $\left(X_{S}\right.$ $\left.<X^{*}, Y_{S}<Y^{\prime \prime}\right)$ e, consequentemente, produzirá menos.

Em suma, o modelo teórico de restrição de crédito assimétrica possui as implicações a seguir descritas.

1) Em primeiro lugar, caso a firma não possua restrições de crédito, o acesso a este não afeta a alocação de insumos nem seu nível de produção.

2) Em segundo lugar, na presença de restriçôes de crédito, o relaxamento da restrição resultará no aumento do produto. Contudo, o impacto do relaxamento sobre a escala no uso de insumos é ambíguo:

a) o relaxamento da restrição de crédito, quando assimétrica, resultará no aumento tanto da produção quanto do uso do insumo restrito;

b) o relaxamento da restrição de crédito, quando assimétrica, resultará na redução do uso do insumo irrestrito caso o efeito substituição seja mais intenso que o efeito escala e vice-versa; e

c) o relaxamento da restrição de crédito, quando simétrica, resultará no aumento da escala de produçấo e do uso de ambos os insumos.

Para o caso das firmas da regiáo Norte, o FNO é uma das políticas públicas que visam à correção de falhas do mercado de crédito e, especificamente, o relaxamento de restriçôes de crédito que, como visto, reduz a capacidade produtiva das empresas. Tanto a política como as firmas da região possuem características distintas que devem ser levadas em consideração.

\subsection{0 modelo teórico para restrição de crédito assimétrica sujeito ao relaxamento das restrições via FNO}

A política de concessão de crédito subsidiado vinculada ao FNO tem como principais diretrizes a geração de novos postos de trabalho, a ampliação da massa salarial (renda), o aumento da produtividade e a promoção do desenvolvimento 
econômico na regiáo Norte. Os programas de crédito associados ao FNO preveem recursos com as finalidades de financiamento de custeio e capital de giro para insumos (exceto trabalho) e matérias-primas, além de investimentos em capital necessários a atividade produtiva.

Seguindo os modelos de Blancard et al. (2006) e Ciaian, Falkowski e Kancs (2012), para modelar o caso em questão, retoma-se a função (tecnologia) de produção com retornos constantes à escala $(f(X, Y))$, de uma firma representativa da regiáo Norte, que depende de dois insumos, $X$ e $Y$. Pode se atribuir a $Y$ o vetor de insumos e matérias-primas, inclusive trabalho, variáveis no curto prazo: $Y=$ $[L, R]$, em que $L$ representa o insumo trabalho e $R$ os demais insumos e matérias-primas variáveis no curto prazo. Já o vetor $X$ agrega o capital ou os insumos fixos no curto prazo: $X=[K]$, em que $K$ representa o investimento em capital da firma ou os insumos fixos no curto prazo.

Pela definição dos insumos, uma premissa adicional ao modelo é a de reduzida taxa de substituição entre eles, o que implicará um multiplicador de Lagrange com menor valor absoluto, ou, em outras palavras, em um menor lucro marginal do relaxamento da restrição. O lucro continua a ser definido por: $\Pi=p f(X, Y)-w_{X} X-w_{Y} Y$.

A firma representativa da região Norte possui montante $C+\tau$ disponível para o financiamento da aquisição de insumos. Sendo que $\tau$ representa um montante de crédito disponível à empresa por meio dos programas do FNO. As demais definições são as mesmas apresentadas anteriormente. Assim a restrição (1) toma a seguinte forma:

$$
\alpha w_{X} X+\delta w_{Y} Y \leq C+\tau \text {. }
$$

A firma representativa da região Norte maximiza lucros sujeita a restrição de crédito (10) de acordo com o seguinte Lagrangeano:

$$
H=p f(X, Y)-w_{X} X-w_{Y} Y-\theta\left[\alpha w_{X} X+\delta w_{Y} Y-(C+\tau)\right] \cdot
$$

As condiçôes de primeira ordem (CPOs) para máximo são definidas agora por (3), (4) e (10). Na situação em que a empresa náo possui nenhum tipo de restrição de crédito $(\theta=0)$, a firma não demanda crédito do mercado financeiro $(\tau=0)$. Como a firma não possui restrição de crédito, tanto o nível de produção quanto o de utilização de insumos não são afetados, ou seja, como o montante de crédito disponível para essa empresa é irrelevante, ele não apresentaria impacto nos termos definidos pelo FNO.

Com restrição de crédito assimétrica, $X(\alpha=1$ e $\delta=0)$ ou $Y(\alpha=0$ e $\delta=1)$, provocada por uma redução na liquidez da firma de $C$ para $C_{1}\left(C_{1}<C\right)$, e quando a empresa não tem acesso ao crédito $(\tau=0)$ as implicaçóes são distintas para a regiáo Norte. Para a restriçẫo de crédito assimétrica no insumo $X$ (capital), $X(\alpha=1$ e $\delta=0)$, o 
efeito escala deve ocorrer no mesmo sentido da situação genérica, reduzindo o nível do produto e o de utilização de insumos. No entanto, o efeito substituição deve ser inferior ao efeito escala devido à menor taxa marginal de substituição entre os insumos $X \mathrm{e} Y$. A força do efeito substituição será determinada pelo ajustamento da relação de preços em relação ao preço sombra $\theta_{1}$, de $w_{X} /\left.w_{Y}\right|_{*} \operatorname{para}\left(1+\theta_{1}\right) w_{X} /\left.w_{Y}\right|_{A S}$. Com $\theta_{1}<\lambda_{1}$, a substituição entre $X$ e $Y$ será menor e o novo ponto de equilíbrio deve apresentar um nível de insumo irrestrito intermediário entre $Y^{*}$ e $Y^{A S^{\prime}}$; em outras palavras, para o caso da regiáo Norte, a restrição de crédito assimétrica reduz tanto o produto quanto os insumos em relação à situação de ausência de restrição $(\theta=0)$, contudo, a redução do insumo irrestrito se dá em menor magnitude.

Para a situação em que a empresa possui acesso ao crédito, deve-se levar em consideração que esse crédito não pode ser utilizado para aquisição de trabalho. Quando as empresas enfrentam restriçóes de crédito com assimetria para o capital, o insumo substituto é o trabalho, mas, como observado, a menor taxa de substituição faz com que o trabalho também esteja em nível inferior ao ótimo. Mesmo assim, o efeito da restrição de crédito assimétrica é a mudança na intensidade de uso dos insumos, pois existem mais unidades de trabalho por unidade de capital no novo equilíbrio em relação ao ótimo. Pelo princípio dos retornos marginais decrescentes isso provoca queda na produtividade do fator trabalho o que implica menores salários.

No caso em que a restrição de crédito se dá no insumo $X$ (capital), $X(\alpha=1$ e $\delta=0)$, e a firma tem acesso a um montante de crédito $\left(\tau \geq C-C_{1}\right)$, tanto a produção quanto a utilizaçáo de insumos aumentam, movendo o equilíbrio em direção ao ponto ótimo. O aumento da aquisição de capital, nesse caso, será maior em relação ao aumento dos insumos variáveis no curto prazo devido à assimetria da restrição. Mesmo que o crédito não contemple aquisição de trabalho, os retornos constantes à escala e o aumento da produção geram novos postos de trabalho (equilíbrio). Como consequência do relaxamento da restrição de crédito, mais unidades de capital são disponibilizadas por unidade de trabalho, o que aumenta a produtividade. ${ }^{5}$ Para um montante de crédito inferior ao necessário $\left(\tau<C-C_{1}\right)$, o ponto de equilíbrio move-se em direção ao ótimo, aumentando os níveis de produto e do insumo $X$, no entanto, o aumento do insumo $Y$, inclusive trabalho, dependerá do volume de crédito $(\tau)$ disponibilizado.

Caso a restrição ocorresse com relação ao insumo $Y$ (trabalho, matéria-prima), $Y(\alpha=0$ e $\delta=1)$, a empresa enfrentaria restrição de crédito assimétrica em insumos de curto prazo e o equilíbrio se afastaria da situação ótima $(\theta=0)$, pelo efeito escala. Novamente, ocorre substituição de fatores pelo fato do produto marginal do insumo

5. Está consolidado na literatura econômica que o salário médio é um indicador de produtividade, portanto, aumentos no salário médio devem indicar aumento de produtividade média. 
$Y$ ser maior que seu preço. A substituição, dessa vez, ocorre em favor do insumo $X$. Mais uma vez, a restrição de crédito resulta em menor produção e menor nível de utilização de insumos, no entanto, a produção é capital intensiva, uma vez que a firma possui menor dificuldade de aquisição desse insumo.

Quando a firma possui acesso ao crédito e como a restrição ocorre com relação ao nível de $Y$, ambas as situaçóes $\left(\tau \geq C-C_{1}\right)$ e $\left(\tau<C-C_{1}\right)$ resultariam no aumento do produto e na utilização do insumo $Y$ (inclusive trabalho). Dessa vez o aumento dos insumos variáveis no curto prazo (inclusive trabalho) será proporcionalmente maior que o de capital devido à assimetria na restrição.

$\mathrm{Na}$ região Norte, portanto, restriçóes de crédito assimétricas reduzem o produto de equilíbrio e diminuem o uso tanto do insumo restrito quanto do insumo irrestrito em relação à situação em que não existem restriçôes ao crédito, ao contrário do modelo inicial, da subseçáo 2.1, onde o uso do insumo irrestrito poderia aumentar em relação à situação sem restrições de crédito. Em relação às finalidades de crédito, ao acessar crédito para investimento, a firma revela que possui restriçóes de liquidez mais severas em relaçáo aos insumos fixos no curto prazo, em outras palavras, o acesso ao crédito faz com que o aumento proporcional de capital seja maior que o de insumos variáveis no curto prazo. $\mathrm{O}$ mesmo acontece quando a firma acessa crédito para capital de giro e custeio, revelando possuir restriçóes assimétricas na aquisição de matéria-prima e insumos variáveis no curto prazo, nesse caso o aumento ocorrerá em favor destes.

Por sua vez, enfrentando restrições de crédito simétricas em ambos os insu$\operatorname{mos}(\alpha=1, \delta=1, \tau=0)$, as firmas reduzem tanto o uso de insumos quanto o nível de produto, o resultado não seria diferente do apresentado nas equaçôes (6), (7) e (8). Considere uma redução no crédito disponível de $C$ para $C_{2}\left(C_{2}<C_{1}<C\right)$. Em relação à situação em que não há restrição de crédito, uma quantidade menor de crédito $C_{2}$ provoca um equilíbrio paralelo à situação ótima. A restrição de crédito simétrica não afeta o produto marginal relativo, portanto, somente o efeito escala ocorre.

Caso as firmas possuam acesso ao crédito, duas situaçóes podem ocorrer $(\tau \geq$ $\left.C-C_{2}\right)$ e $\left(\tau<C-C_{2}\right)$. No primeiro caso, o valor em crédito é suficiente para que o equilíbrio se desloque para o ponto ótimo, gerando emprego e renda e aumentando a produtividade. Já no segundo caso, o montante em crédito é suficiente apenas para deslocar o ponto de equilíbrio para um ponto com maior produto e maior utilização dos insumos, mas insuficiente para alcançar o ponto ótimo, não estando garantidas a geraçấo de emprego e renda e o aumento da produtividade.

Do modelo teórico de restrição de crédito assimétrica para a região Norte é possível extrair as implicaçóes a seguir. 
1) Caso a firma não possua restrições de crédito, $\mathrm{o}$ acesso ao crédito não afeta a alocação de insumos nem seu nível de produção, implicando impacto nulo sobre a geração de emprego e a massa salarial e sobre a produtividade.

2) Na presença de restrição de crédito, o relaxamento desta resultará no aumento do produto. Contudo, o impacto sobre a geração de emprego, a massa salarial e a produtividade dependerá do montante e do tipo de acesso ao crédito:

a) o relaxamento da restrição de crédito assimétrica sobre o capital resultará no aumento tanto da produção quanto do uso dos insumos, com maior aumento relativo para o insumo capital, além disso, ocorre geração de empregos e aumento na massa salarial e na produtividade se $\left(\tau \geq C-C_{1}\right)$;

b) o relaxamento da restrição de crédito assimétrica sobre insumos variáveis no curto prazo resultará no aumento da produção e em maior aumento relativo do uso dos insumos variáveis no curto prazo, sendo o impacto sobre emprego, portanto, maior que na finalidade investimento, já a produtividade e a massa salarial podem aumentar se $\left(\tau \geq C-C_{1}\right)$; e

c) o relaxamento da restrição de crédito simétrica resultará no aumento da escala de produção e no uso de ambos os insumos, na mesma proporção, gerando também impacto sobre emprego, massa salarial e produtividade se $\left(\tau \geq C-C_{2}\right)$.

\section{MÉTODOS EMPREGADOS}

\subsection{0 estimador de diferenças em diferenças}

Com o intuito de atender ao objetivo de alterar padróes, sejam de renda, crescimento econômico, saúde, entre outros, um volume significante de recursos públicos é destinado ao orçamento de programas de intervenção governamental.

A avaliação de impacto visa, por sua vez, a mensuração do efeito de tratamento ou de intervenção de algum programa público sobre algum produto ou indicador socioeconômico de interesse. Geralmente, esse tratamento é atribuído a algum grupo de interesse (tratados) e o grupo que não recebe tratamento é chamado de grupo de controle. É de interesse, portanto, saber o impacto desse tratamento sobre o grupo tratado em relação ao grupo de controle. No presente trabalho, o programa de tratamento é o FNO, cujo objetivo é o relaxamento da restrição de crédito dos empreendimentos e, por conseguinte, o aumento da produtividade, da geração de emprego e renda, desencadeando o crescimento e o desenvolvimento 
econômico regional. O grupo de tratamento seria composto pelos empreendimentos que receberam recursos provenientes do FNO e o grupo de controle pelos que não receberam. ${ }^{6}$

Quando se aborda a análise de impacto dos fundos constitucionais de financiamento, em nível de firmas, a literatura (Braga et al., 2012; Silva, Resende e Silveira Neto, 2006; 2009; Sousa, Nottingham e Gonçalves, 2010; Soares et al., 2013) tradicionalmente busca identificar impactos sobre o estoque de emprego, massa salarial e salário médio. O objetivo da análise de impacto é mensurar a diferença existente nos produtos entre os grupos tratados e de controle para verificar o efeito da intervenção. Os modos mais comuns de se auferir o efeito de tratamento são o efeito médio de tratamento (em inglês, average treatment effect - ATE) e o efeito médio de tratamento sobre os tratados (em inglês, average treatment effect on the treated - ATET).

O ATE pode ser definido como a diferença média existente nos produtos entre os grupos tratados e de controle:

$$
\mathrm{ATE}=E\left(y_{1}-y_{0}\right)=E\left(y_{1} \mid X, D=1\right)-E\left(y_{0} \mid X, D=0\right),
$$

em que $y_{1}$ e $y_{0}$ representam as variáveis de interesse (estoque de emprego, massa salarial e salário médio) para os grupos tratado e de controle, respectivamente, $D$ identifica os grupos tratados (1) e de controle (0) e $X$ é o vetor de características dos empreendimentos. Segundo Khandker, Koolwal e Samad (2009), o problema do ATE é que os grupos tratados e de controle podem não ter a mesma prioridade de intervenção, então, a diferença média observada entre eles pode não ser totalmente devida ao programa.

O problema ocorre devido à dificuldade de se definir o contrafactual (o que teria ocorrido com o grupo de tratados caso náo tivessem recebido o tratamento). Ao contrário dos experimentos controlados, nos estudos observacionais a decisão de participar do tratamento não é aleatória devido aos propósitos do programa e a autosseleção ao tratamento. Ao estimar o ATE por regressão linear, o fato de características observáveis e não observáveis estarem relacionadas à participação no programa $(D=1)$ introduz correlação entre o termo de erro e a variável de tratamento $(D)$, isso viola um dos pressupostos do modelo clássico de regressáo linear (MCRL), causando viés e inconsistência nas estimativas de mínimos quadrados ordinários (MQO) do efeito médio de tratamento, conhecido nessa abordagem como viés de seleção ou viés de autosseleção.

6. Por uma limitação de acesso aos dados, o grupo tratado será composto exclusivamente de beneficiários do FNO. Como este programa tem características e objetivos específicos, a interpretação será de comparação do impacto do FNO em relação às empresas que não receberam benefícios do programa mesmo que tenham recebido de outros programas. 
Para evitar o problema, utiliza-se em estudos observacionais o segundo modo de mensurar o ATE (ATET), definido como a diferença média observada nos produtos entre o grupo de tratados e o mesmo grupo caso não tivesse recebido tratamento:

$$
\mathrm{ATET}=E\left(y_{1}-y_{0} \mid D=1\right)=E\left(y_{1} \mid X, D=1\right)-E\left(y_{0} \mid X, D=1\right),
$$

em que o último termo representa o contrafactual. Como não é possível observar o contrafactual ele deve ser estimado. O método de estimação utilizado pelos estudos anteriormente citados foi o PSM.

Nesse método, o contrafactual é construído com base no grupo que não recebeu recurso/tratamento pelo pareamento com empreendimentos que receberam o recurso/tratamento. $\mathrm{O}$ procedimento consiste na estimação de um modelo de propensão (logit/probit) a participar do programa (receber recursos) em função de características observáveis. A partir do modelo, obtém-se o escore ou a probabilidade de fazer parte do programa e através de algum método (Kernel, vizinho mais próximo, estratificação, Mahalanobis) ocorre o pareamento formando o contrafactual. Pode se, então, definir o ATET da seguinte forma:

$$
\mathrm{ATET}=E\left(y_{1}-y_{0} \mid p(X), D=1\right)=E\left(y_{1} \mid p(X), D=1\right)-E\left(y_{0} \mid p(X), D=0\right)
$$

em que $p(X)=\operatorname{prob}(D=1 \mid X)=E(D \mid X)$ é a probabilidade ou escore de propensão do empreendimento receber recursos dadas suas características.

Apesar de mais adequado que o ATE, para estudos observacionais, o ATET mensurado com a ajuda do PSM ignora a existência de heterogeneidade não observável, levando ao viés de seleção, caso presente. Dada a divergência de resultados da literatura, na presença de restriçôes de crédito, essa hipótese parece ser suficientemente forte para se sugerir a abordagem a partir de método mais adequado. O método DD para dados longitudinais seria uma alternativa mais robusta nesse caso.

$\mathrm{O}$ método DD assume que a heterogeneidade, que afeta a participação das firmas no programa, está presente e é invariante no tempo. Nesse caso, o ATET é estimado tomando-se as diferenças nos produtos entre os grupos tratados e de controle antes e depois da intervenção do programa. Ao fazer comparaçóes antes e depois da intervenção e entre os empreendimentos que receberam e não receberam tratamento, o DD produz uma estimativa mais consistente do contrafactual. O ATET estimado pelo método DD é definido como:

$\mathrm{ATET}=E\left(\left(y_{1}^{a}-y_{0}^{a}\right)-\left(y_{1}^{d}-y_{0}^{d}\right) \mid X, D=1\right)=E\left(\left(y_{1}^{a}-y_{1}^{d}\right)-\left(y_{0}^{a}-y_{0}^{d}\right) \mid X, D=1\right)$,

em que o primeiro termo à direita refere-se à diferença nos produtos antes $(a)$ e depois $(d)$ do tratamento para o grupo tratados. Este termo pode estar enviesado devido a tendências no tempo, como inflação, crescimento econômico, entre outras. 
O segundo termo à direita usa diferenças nos produtos do grupo de controle para remover a possibilidade desse viés.

Para controlar a heterogeneidade observada e não observada, considere a seguinte regressão de efeitos fixos:

$$
y_{\mathrm{it}}=\alpha_{i}+\delta D_{\mathrm{it}}+\beta X_{\mathrm{it}}+\varepsilon_{\mathrm{it}},
$$

em que $\delta$ é o parâmetro vinculado à variável que indica a participação no programa, $\alpha$ são os efeitos fixos invariantes no tempo que controlam a heterogeneidade não observada, $\beta$ é o vetor de parâmetros das variáveis contextuais que controlam a heterogeneidade observada e $\varepsilon$ é o termo de erro da regressão. Diferenciando ambos os lados de (16) obtém-se:

$$
\begin{aligned}
& \left(y_{\mathrm{it}}-y_{\mathrm{it}-1}\right)=\left(\alpha_{i}-\alpha_{i}\right)+\delta\left(D_{\mathrm{it}}-D_{\mathrm{it}-1}\right)+\beta\left(X_{\mathrm{it}}-X_{\mathrm{it}-1}\right)+\left(\varepsilon_{\mathrm{it}}-\varepsilon_{\mathrm{it}}\right) . \\
& \Delta y_{\mathrm{it}}=\delta \Delta D_{\mathrm{it}}+\beta \Delta X_{\mathrm{it}}+\Delta \varepsilon_{\mathrm{it}} .
\end{aligned}
$$

Com a eliminação dos efeitos fixos, a heterogeneidade não observável não está mais presente. Dessa forma, o método de MQO pode ser aplicado a (17b), gerando estimativa náo enviesada do ATET, definido como $(\delta)$.

Segundo Bertrand, Duflo e Mullainathan (2002) e Imbens e Wooldridge (2009), as estimaçóes feitas pelo procedimento DD são tipicamente afetadas por problemas de autocorrelaçáo devido à natureza das variáveis dependentes que, juntamente com o problema de heterocedasticidade, tornam as estimativas dos erros-padrão inválidas. Nesse sentido, Cameron e Trivedi $(2005 ; 2009)$ sugerem que, para painéis curtos, especialmente, seja feita a correção robusta por cluster para que a verdadeira matriz de variância e covariância dos coeficientes seja estimada, corrigindo os problemas.

Outro problema do estimador DD refere-se à pressuposição de tendência comum entre os grupos de controle e tratado. Esta pressuposição assegura que não é necessária a existência de uma regiáo de suporte comum de propensão a participar do tratamento para estimação do impacto econômico, no entanto, ela exige que as tendências dos produtos dos grupos sejam iguais caso não houvesse tratamento. A pressuposição garante que o resultado encontrado se deve ao tratamento (Gertler et al., 2011). Não é possível verificar formalmente a pressuposição, contudo, a literatura sugere que sejam feitos testes de robustez. Um dos testes inclui modelos em que o tratamento ocorreria em outros pontos e não no ponto onde realmente ocorre o tratamento, ou seja, incluem-se avanços e defasagens (leads and lags) nos modelos para verificar se existe causalidade entre o momento do tratamento e a resposta em termos de impacto. Os avanços devem ser náo significativos enquanto 
pelo menos uma das defasagens deve ser significativa. Tal comportamento geraria evidências de que o impacto observado realmente deve-se à intervençâo do programa.

\subsection{0 modelo econométrico}

O modelo analítico usado é definido pela equação (14), que estabelece os determinantes do produto $y$ na firma $i$ no ano $t$, podendo ser avaliada com base no modelo econométrico a seguir.

$$
\ln y_{\mathrm{it}}=\alpha_{i}+\varphi_{t}+\delta D_{\mathrm{it}}+\beta X_{\mathrm{it}}+\varepsilon_{\mathrm{it}}
$$

A variável $y_{i t}$ representa os produtos na firma $i$ e no ano $t$, aos quais se tem interesse em verificar a efetividade do programa de concessão de crédito vinculado ao FNO, quais sejam: estoque de emprego (capta a geração de emprego), massa salarial (capta a geração de renda) e salário médio (capta a produtividade média do trabalho). As variáveis massa salarial e salário médio foram mensuradas em preços constantes de 2010 com base no Índice Nacional de Preços ao Consumidor (INPC). Utilizou-se a transformação logarítmica nesta variável devido a seus bons atributos econométricos, como a compressão das unidades de dispersão com relação à média, a maior propensão à normalidade e a interpretação de semielasticidade. Cada produto possui uma estimação específica e o período $t$ compreende os anos entre 2000 e 2010.

Os parâmetros $\alpha_{i}$ e $\varphi_{t}$ representam os efeitos fixos invariantes no tempo para as firmas e os efeitos fixos invariantes nas firmas para os anos, respectivamente, que controlam a heterogeneidade náo observada entre as firmas e no tempo. $\mathrm{O}$ vetor $\delta$ representa o efeito que a participaçáo no programa $D$ exerce sobre o produto $y$. A participação no programa $D$ é dividida de acordo com a finalidade do crédito, sendo para capital de giro e custeio ou investimento, são quatro variáveis dicotômicas. Duas delas representam a participação no programa de acordo com a finalidade no ano em que a empresa recebe o crédito, as outras duas definem a participação no programa a partir do ano em que receberam crédito. Cada definição de participação inicial ou contínua possui uma estimação específica.

$O$ vetor $\beta$ representa o efeito que cada uma das variáveis observadas $X$ exerce sobre o produto $y$. As características observáveis das firmas $X$ s incluídas na definição dos produtos são as a seguir.

1) PIB per capita do município (R\$ mil): esta variável define o PIB per capita do município, em $\mathrm{R} \$ 1$ mil, onde se localiza a firma. Incluída com o objetivo de captar a dinâmica da economia local que pode influenciar na geração de emprego e renda e no nível de produtividade. A variável foi mensurada em preços constantes de 2010 com base INPC. 
2) Tamanho da empresa: define o porte da empresa em termos do número de funcionários. O tamanho da empresa é um dos determinantes da dinâmica dos produtos de interesse. São duas definiçóes, micro e pequena e média e grande. De acordo com Sebrae e Dieese (2013), as firmas foram classificadas da seguinte forma: para os setores primário e terciário, como micro e pequenas empresas aquelas com até 49 funcionários; e como média e grande, aquelas com número de funcionários superior à 49. Já para o setor secundário, foram definidas como micro e pequenas empresas aquelas com até 99 empregados; e como média ou grande, aquelas com número de funcionários superior a 99. Cada definição de tamanho, assim como o agregado de firmas, possui estimação específica.

3) Setor de atividade: define o grande setor de atividade no qual a firma atua. Também considerada importante para a dinâmica das variáveis de produto. São três variáveis categóricas: cada uma define um grande setor de atividade econômica, como primário, secundário e terciário. Cada setor de atividade, assim como a economia como um todo, possui uma estimação específica.

4) Estado: conjunto de variáveis dicotômicas que identifica o estado no qual está localizada a firma. A economia pode apresentar trajetória divergente em cada estado devido a uma série de características. Para a regiáo Norte, identificam-se os estados do Acre, do Amapá, do Amazonas, do Pará, de Rondônia, de Roraima e do Tocantins.

5) Tendência: define a evolução linear do tempo. Os comportamentos das variáveis de produto podem sofrer influência das tendências da economia do país como um todo.

6) Nivel de qualificação: define o nível de escolaridade do conjunto de funcionários de uma firma, representa o nível de qualificação e, até mesmo, o nível de agregação de valor dos produtos de uma firma. Tal fator exerce influência sobre a dinâmica dos produtos de interesse. É um conjunto de seis variáveis que identificam a proporção dos funcionários nos seguintes níveis de escolaridade: analfabeto, fundamental incompleto, fundamental completo, ensino médio completo, superior completo e pós-graduação completa.

7) Tratamento (D): esta variável categórica, caracterizada como efeito inicial ou contínuo (curto e longo prazo), define quando a empresa é tratada. A definição de curto prazo assume valor 1 para o ano em que a empresa recebe recursos do FNO e valor 0 caso contrário. Já a definição de longo prazo assume valor 1 a partir do ano em que a empresa recebe crédito proveniente do FNO e 0 para o período anterior. 
Finalmente, $\varepsilon$ é o termo de erro da regressão - equação (16). Dados os vários recortes do experimento, foram estimadas 72 regressóes a partir do estimador DD ou MQO com efeitos fixos e correção robusta por cluster para heterocedasticidade e autocorrelação, de acordo com o tamanho das firmas, o setor de atividade e a finalidade de crédito.

\subsection{Fonte e procedimentos para a formação da base de dados}

As bases de dados em nível de firmas foram cedidas pelo Basa e pelo MTE sob acordo de confidencialidade, devido à presença de algumas informaçóes, como Cadastro de Pessoa Física (CPF) e Cadastro Nacional da Pessoa Jurídica (CNPJ), dos beneficiários.

A base de dados fornecida pelo Basa refere-se aos contratos firmados entre o banco (aplicador dos recursos do $\mathrm{FNO}^{7}$ e os beneficiários. O banco de dados possui informaçóes de 439.904 contratos firmados entre 1989 e 2011 . Informaçóes sobre a agência onde foi realizado o contrato, sobre o CPF ou CNPJ beneficiário, porte, setor de atividade, valor e finalidade foram disponibilizados.

A base de dados fornecida pelo MTE é referente à Relação Anual de Informaçóes Sociais (Rais) que deve ser entregue anualmente e obrigatoriamente pelas empresas que se enquadrem nos critérios delimitados pelo ministério. A Rais está disponível nas bases de dados on-line do MTE, no entanto, sem a identificaçấo das firmas a partir do CNPJ. A Rais possui como unidade de observação os funcionários das empresas. O banco de dados possui informaçóes de 4.187.674 funcionários de empresas declarantes da Rais na regiáo Norte entre 2000 e 2010. Informaçôes como CNPJ das empresas, idade, escolaridade e remuneração dos funcionários, município e setor de atividade da firma foram disponibilizadas.

A princípio, os dados da Rais foram organizados em informaçóes por empresa ao invés de informações individuais dos funcionários, reduzindo assim o número de observaçóes para 229.295. As variáveis foram convertidas em agregados por empresa, como idade média, proporção de funcionários por grau de instrução, remuneração média, massa salarial e estoque de emprego (número de funcionários).

Posteriormente, utilizando o mesmo recorte de tempo, 2000 a 2010, os dados de contratos do Basa também foram convertidos em dados agregados em empresas, houve essa necessidade devido ao fato de que algumas empresas possuíam vários contratos no mesmo ano, que foram somados. Assim, foram utilizadas as informaçôes das empresas beneficiárias para juntá-las às informações da Rais, o que

7. A partir das Portarias Ministeriais no 23/2017 e no 147/2018, do então Ministério da Integração Nacional (MIN), é possível que outros bancos operem com os fundos constitucionais. 
foi possível por meio da informação do CNPJ. Dessa forma, 1.502 observaçóes que faziam parte de ambas as bases de dados foram adicionadas aos dados da Rais, formando entáo a base de dados utilizada com 229.295 observaçóes. O expressivo número de observações deletadas deve-se ao fato de não haver correspondência na Rais para com as informaçóes obtidas do Basa. Em torno de 97,3\% das observaçóes do período 2000-2010 eram referentes a pessoas físicas e 2,7\% de pessoas jurídicas. Por vários motivos, entre os quais estão a não obrigatoriedade de declarar a Rais e a informalidade, as pessoas físicas não possuem informaçóes na Rais inviabilizando a utilização dessa observação.

O grupo tratado é formado por $0,01 \%$ de pessoas físicas e de $99,9 \%$ de pessoas jurídicas. Apesar de o fato representar uma limitação do trabalho, acredita-se que esse cenário não invalida as evidências obtidas, uma vez que a amostra apresenta um valor significativo quando se compara com o total concedido. Entre 2000 e 2010, o Basa concedeu R \$ 17,3 bilhôes (preços de 2010) em crédito a projetos produtivos na regiâo Norte. Desse total, a amostra de empreendimentos de que dispóe o presente estudo totaliza cerca de R 3 bilhóes em crédito, ou seja, 17,8\% do total. Demais procedimentos já foram descritos anteriormente, como a deflação dos valores monetários para preços de 2010, de acordo com o INPC.

\section{RESULTADOS E DISCUSSÃO}

Nesta seção são apresentados os resultados e as discussóes relacionadas ao impacto econômico da política de crédito vinculada ao FNO sobre a geraçáo de emprego e a massa salarial e sobre o aumento da produtividade média do trabalho. Por simplicidade, são apresentados apenas os coeficientes estimados pelo método DD vinculados ao impacto do FNO, apesar da utilização dos controles para efeitos fixos para unidade e tempo (heterogeneidade não observável), estado de localização, PIB per capita municipal, escolaridade média dos funcionários, tamanho e setor de atividade da empresa. Os resultados completos podem ser consultados no apêndice A, contudo, em geral se observa que as variáveis de controle são importantes para explicar a variável dependente. Em média, estar localizado no Pará e em municípios com maior PIB per capita representa uma vantagem para a empresa. Empresas e níveis de escolaridade maiores tendem a representar maior geração de emprego, massa salarial e salário médio.

A tabela 1 apresenta os resultados das estimaçóes de avaliaçâo de impacto dos recursos destinados pelo FNO ao setor produtivo sobre o estoque de emprego, a massa salarial e o salário médio. 
TABELA 1

Impactos econômicos sobre estoque de emprego, massa salarial e salário médio, segundo o setor da economia e o tamanho da empresa em relação às empresas não beneficiárias

(Em \%)

\begin{tabular}{|c|c|c|c|c|c|c|c|c|c|c|c|c|c|}
\hline \multirow{2}{*}{$\begin{array}{l}\text { Setor } \\
\text { Porte da empresa }\end{array}$} & & \multicolumn{3}{|c|}{ Primário } & \multicolumn{3}{|c|}{ Secundário } & \multicolumn{3}{|c|}{ Terciário } & \multicolumn{3}{|c|}{ Todos } \\
\hline & & MP & MG & ALL & MP & MG & ALL & MP & $M G$ & ALL & MP & MG & ALL \\
\hline \multirow{2}{*}{ Curto prazo } & Giro e custeio & 19,5 & - & 13,8 & 22,7 & 14,0 & 18,5 & 65,3 & 37,8 & 58,7 & 23,1 & 12,1 & 19,1 \\
\hline & Investimento & 15,5 & - & 12,3 & 5,5 & 8,4 & 7,6 & 47,8 & 19,8 & 37,4 & 13,0 & 11,1 & 13,3 \\
\hline \multirow{2}{*}{ Longo prazo } & Giro e custeio & 35,0 & - & 22,7 & 21,5 & - & 16,1 & - & 41,8 & 42,5 & 19,6 & - & 14,4 \\
\hline & Investimento & - & - & - & 36,2 & - & 32,7 & 69,5 & 17,4 & 48,7 & 33,3 & 9,89 & 28,0 \\
\hline \multirow[b]{2}{*}{ Curto prazo } & Giro e custeio & 20,0 & - & 14,4 & 21,60 & 13,20 & 19,1 & 64,8 & 43,9 & 61,1 & 22,7 & 12,5 & 20,0 \\
\hline & Investimento & 14,7 & - & 12,8 & 5,25 & 8,95 & 7,43 & 49,7 & - & 37,3 & 12,8 & 9,05 & 13,1 \\
\hline \multirow{2}{*}{ Longo prazo } & Giro e custeio & 31,2 & - & 19,0 & 24,1 & - & 17,9 & - & 50,8 & 47,0 & 21,3 & - & 15,2 \\
\hline & Investimento & - & - & - & 35,0 & - & 31,8 & 77,4 & - & 52,8 & 33,2 & 10,0 & 27,7 \\
\hline \multirow{2}{*}{ Curto prazo } & Giro e custeio & - & - & - & - & - & - & - & - & - & - & - & - \\
\hline & Investimento & - & - & - & - & - & - & - & - & - & - & - & - \\
\hline \multirow{2}{*}{ Longo prazo } & Giro e custeio & - & - & - & 4,33 & - & 3,44 & - & - & 7,13 & - & - & - \\
\hline & Investimento & - & - & - & - & 5,22 & 2,15 & 9,08 & - & - & - & - & - \\
\hline
\end{tabular}

Fonte: Resultados da pesquisa.

Elaboração dos autores.

Obs.: 1. MP = micro e pequenas empresas; $M G$ = médias e grandes empresas; $A L L=$ todas as empresas.

2. Controles: efeitos fixos para unidade e tempo; estado de localização; PIB per capita; escolaridade média dos funcionários; tamanho e setor de atividade da empresa.

3. (-) indica ausência de impacto, demais resultados significativos pelo menos ao nível de $10 \%$ de significância.

$\mathrm{Na}$ tabela 1, os resultados estão divididos por setor de atividade econômica (primário, secundário, terciário e todos os setores reunidos), finalidade de crédito (investimento ou capital de giro e custeio), tamanho da empresa (micro e pequena, média e grande e todas as empresas reunidas) e período de ação do crédito, definido como curto e longo prazo (impacto inicial e contínuo). O impacto inicial (curto prazo) é caracterizado pelo ano em que a empresa recebeu o crédito ou a primeira parcela do benefício, já o impacto contínuo (longo prazo) indica o período a partir do qual a empresa recebeu crédito ou a primeira parcela do benefício. Os testes de avaliação do modelo (multicolineridade, heterocedasticidade e autocorrelação) foram realizados e a correçáo robusta por cluster para heterocedasticidade e autocorrelação aplicadas quando necessárias. Os testes de robustez, apêndice A, em geral ratificam a existência de diferença média (impacto) nos produtos a partir do tratamento. 


\subsection{Impacto da política de crédito sobre a geração de emprego}

Em termos de impacto econômico e social, a variável emprego é a de maior relevância em relação ao que se espera da aplicação do FNO. A geração de empregos sugere aumento de produção e da geração de renda, elevando o dinamismo da economia e promovendo crescimento e desenvolvimento econômico. Os resultados são apresentados de acordo com o setor e os efeitos iniciais e contínuos, aqui chamados de curto e longo prazo (tabela 1).

Em relação ao curto prazo (impacto inicial) no setor primário, impactos positivos e estatisticamente significativos são observados sobre a geração de emprego em micro e pequenas empresas, independentemente da finalidade do crédito recebido. As micro e pequenas empresas do setor primário que receberam crédito para capital de giro e custeio apresentaram estoque de emprego 19,5\% maior em relação às empresas não beneficiárias no período 2000-2010, controlados fatores observáveis e não observáveis que afetam a dinâmica desta variável. Já as empresas que receberam crédito para investimento têm estoque de emprego $15,5 \%$ superior às não beneficiárias. Em termos gerais, impactos positivos e significativos indicam que o fato de receber crédito impulsionou a geração de emprego.

Ainda, médias e grandes empresas não apresentaram diferença no estoque de emprego em relação às empresas náo beneficiárias no período inicial, ou seja, os recursos cedidos a essas empresas foram ineficazes na geração de emprego. $\mathrm{O}$ resultado para todas as empresas do setor primário foi positivo e significativo, naturalmente devido ao resultado positivo das micro e pequenas empresas. As empresas que receberam crédito para capital de giro e custeio e para investimento possuem estoque de emprego $13,8 \%$ e 12,3\% maiores que as empresas não beneficiárias, respectivamente.

Para o longo prazo, no setor primário, não é possível identificar impactos positivos em relação ao estoque de emprego para empresas que tenham recebido crédito para investimento. Já para as empresas que receberam crédito para capital de giro e custeio, as micro e pequenas apresentaram um impacto $35 \%$ superior quando comparadas às não beneficiárias, as médias e grandes empresas novamente não têm impacto, e quando reunidas todas as empresas identifica-se um impacto positivo de $22,7 \%$.

Os resultados para o setor primário evidenciam cenário divergente ao exposto por Santos (2010), em que o crédito rural ou mesmo o crédito vinculado ao Programa Nacional de Fortalecimento da Agricultura Familiar (Pronaf) não geram impactos sobre a produtividade da terra e a renda de estabelecimentos beneficiários em relação aos não beneficiários. 
Além disso, o fato de médias e grandes empresas beneficiárias não apresentarem impacto em relação às demais pode estar relacionado ao FNO ter viés de atendimento às micro e pequenas empresas (Funarbe, 2012c; 2012d). Por sua vez, as culturas predominantes na região Norte, como mostrado por Funarbe (2012c; 2012d), são as que atendem à demanda regional, como banana, cacau, mandioca, guaraná entre outras produzidas por estabelecimentos cujas práticas de cultivo ainda são pouco especializadas. Tais culturas, com menor inserção internacional, possuem processos produtivos com menor grau de mecanização e uso de capital, o que acaba por contribuir com a pouca efetividade do crédito. Ainda, as empresas beneficiadas do setor primário recebem em média $54,3 \%$ do valor que recebem, em média, as empresas do setor secundário, ou ainda, cerca de $19 \%$ quando se compara o valor médio recebido pelas empresas do setor terciário. Maior volume de recursos pode potencializar o impacto promovido pelo crédito.

Para o setor secundário, no curto prazo, independentemente do tamanho e da finalidade de crédito, são identificados impactos positivos sobre o estoque de emprego. Entre as micro e pequenas empresas, o estoque de emprego é $22,7 \%$ e $5,5 \%$ superior em relaçáo as não beneficiárias para capital de giro e custeio e para investimento, respectivamente. Para as médias e grandes empresas, essa diferença é de $14 \%$ e $8,4 \%$ em favor das beneficiárias para capital de giro e custeio e para investimento, respectivamente. Quando se observa todas as empresas, as beneficiárias apresentam estoque de emprego maior em 18,5\% e 7,6\% para capital de giro e custeio e para investimento, respectivamente.

No longo prazo, as médias e grandes empresas beneficiárias do setor secundário não apresentam impactos sobre o estoque de emprego em relação as que não receberam crédito, independentemente da finalidade do crédito. Contudo, os demais recortes revelam impactos positivos e significativos, nas micro e pequenas o estoque de emprego foi $21,5 \%$ e 36,2\% maior em comparação com não beneficiárias, para capital de giro e custeio e para investimento, respectivamente. As empresas do setor secundário são as grandes beneficiárias em termos do montante de recursos concedidos $(65,8 \%)$ e apresentam impactos positivos sobre a geraçấo de emprego.

Para o setor terciário, no curto prazo, todos os recortes de tamanho apresentaram impactos positivos e significativos sobre o estoque de emprego, independentemente da finalidade do crédito. Os impactos situaram-se nos intervalos de $37,8 \%$ a $65,3 \%$ para capital de giro e custeio e de $19,8 \%$ a $47,8 \%$ para investimento, em relação às empresas não beneficiárias. Para o longo prazo, não se verificam impactos apenas para micro e pequenas empresas quando estas recebem recursos com a finalidade de financiar capital de giro e custeio. Para esta finalidade, as médias e grandes empresas possuem estoque de emprego $41,8 \%$ superior, enquanto todas as empresas apresentam estoque de emprego $42,5 \%$ maior, em 
média, que a situação não beneficiária. Para investimento, no longo prazo todos os recortes de tamanho apresentam impactos positivos e significativos, sendo de $69,5 \%$ para micro e pequenas empresas, $17,4 \%$ para médias e grandes empresas e de $48,7 \%$ quando reunidas todas as empresas beneficiárias. O impacto expressivo em termos de geração de emprego do setor terciário em relação aos demais setores está intrinsecamente relacionado ao tipo de atividades, geralmente intensivas em trabalho, desenvolvidas pelos estabelecimentos deste setor, como serviços públicos, construção civil e educação.

Quando reunidos todos os setores, observa-se, para o curto prazo, que todos os recortes geraram impactos positivos e significativos sobre o estoque de emprego. Os impactos variam de $12,1 \%$ a $23,1 \%$ para empresas que receberam benefícios para capital de giro e custeio em relação às não beneficiárias; já para as que receberam crédito para a finalidade investimento, esse impacto situa-se no intervalo entre $11,1 \%$ e 13,3\%, quando comparado à situação não beneficiária. Em outras palavras, no ano em que recebem crédito, as empresas beneficiárias geram mais empregos em relação à situação que não tivessem recebido crédito (contrafactual), ou ainda, para cada cem empregos gerados pelas empresas não beneficiárias, são gerados entre 110 e 120 empregos pelas empresas beneficiárias com as mesmas características na regiáo Norte.

No longo prazo, os impactos deixam de ser efetivos apenas para as médias e grandes empresas que recebem benefício para capital de giro e custeio, também percebido nos setores primário e secundário para médias e grandes empresas e no setor terciário para micro e pequenas empresas. Para as empresas que recebem crédito para capital de giro e custeio e que apresentaram impacto no longo prazo, as micro e pequenas empresas possuem trajetória de geração de emprego 19,6\% maior, enquanto todas as empresas $14,4 \%$ maior que a situação não beneficiária.

Em resumo, com relação ao impacto da política de crédito do FNO sobre a geração de emprego é possível afirmar que o efeito é em geral positivo para ambas as finalidades de crédito, mas os resultados não mostram impacto para alguns setores e tamanhos de empresas. Segundo a Funarbe (2012d), o FNO tem promovido acesso ao crédito principalmente a micro e pequenos empreendimentos, aumentando seus investimentos em tecnologia, formação de capital humano, diversificação da produção e atendimento às legislaçóes trabalhista e ambiental. Tal fato contribui para explicar o desempenho superior destes estabelecimentos em relação aos de médio e grande porte. Além disso, nota-se que, no curto prazo, a finalidade capital de giro e custeio gera impacto superior à finalidade investimento, resultado que se inverte ao observar o longo prazo, resultado já esperado pelo desenho das linhas de crédito. 
Tais resultados corroboram os encontrados por Silva, Resende e Silveira Neto (2006), que concluíram que o FNO geraria impacto de 32 p.p. sobre a geração de emprego no período 2000-2003; contudo, estão em desacordo com os resultados de Silva, Resende e Silveira Neto (2009) e Braga et al. (2012), os quais inferiram que, nos períodos 2000-2003 e 2000-2010, respectivamente, não é possível identificar impactos sobre a geração de emprego. Os resultados obtidos por técnicas mais robustas, como o DD com dados em painel, fornecem evidências mais consistentes, ou seja, de fato os programas de concessão de crédito que estão vinculados ao FNO geraram impactos positivos sobre a geração de emprego nas empresas beneficiárias da região Norte. No entanto, observa-se que nem todas as empresas apresentam impactos, o que indica que, apesar de gerar impactos, o programa pode ser mais eficiente na alocação de recursos.

\subsection{Impacto da política de crédito sobre a massa salarial}

Outra variável de interesse quando se trata de impactos econômicos promovidos por políticas públicas é a massa salarial ou a renda gerada por determinada firma ao remunerar o fator de produção trabalho. Apesar dos programas não indicarem em seu desenho variáveis para avaliação de impacto ex-post, a massa salarial é comumente utilizada pela literatura especializada para mensurar os impactos econômicos.

No caso do setor primário, as evidências, em termos de impacto econômico, são semelhantes às apresentadas para o caso do estoque de emprego (tabela 1). Ao avaliar o curto prazo, é possível identificar impactos positivos para micro e pequenas empresas e também para todas as empresas reunidas, independentemente da finalidade do crédito. As empresas beneficiárias de crédito para capital de giro e custeio apresentam massa salarial superior às não beneficiárias entre 14,4\% e $20 \%$, já as beneficiárias de crédito para investimento geram renda entre $12,8 \%$ e $14,7 \%$ superior às não beneficiárias. As médias e grandes empresas não apresentam impacto sobre a massa salarial no curto prazo, ou seja, as beneficiárias geram em média o mesmo nível de massa salarial que as não beneficiárias.

Para o longo prazo, as empresas beneficiárias de crédito para a finalidade capital de giro e custeio apresentam impactos positivos e significativos, com exceção das médias e grandes empresas. O impacto varia entre $31,2 \%$ para micro e pequenas empresas a $19 \%$ para todas as empresas reunidas, quando comparadas com as empresas não beneficiárias. Conforme o exposto, é fácil observar que no setor primário apenas micro e pequenas empresas geram impacto econômico tanto sobre a geração de emprego quanto sobre a geração de renda, reforçando a conclusão de que médias e grandes empresas não enfrentam restriçóes de crédito.

No setor secundário, em consonância com os resultados sobre o estoque de emprego, apenas as médias e grandes empresas no longo prazo náo geram 
impactos positivos e significativos, independentemente da finalidade de crédito. No curto prazo, as empresas que recebem crédito para financiar capital de giro e custeio apresentam, em média, impactos sobre a massa salarial no intervalo de $13,2 \%$ a $21,6 \%$ variando de acordo com o porte da firma. Para crédito vinculado a investimento, o impacto médio varia de 5,25\% a 8,95\% em relação às empresas não beneficiárias. Já no longo prazo, como médias e grandes empresas não têm sua trajetória de geração de renda alterada pelo acesso ao benefício, o impacto positivo da economia como um todo, 17,9\% para capital de giro e custeio e 31,8\% para investimento, é resultado dos impactos auferidos pelas micro e pequenas empresas, $24,1 \%$ e $35 \%$, respectivamente.

O setor terciário, novamente, de acordo com os resultados sobre o estoque de emprego, é o setor que apresenta impactos de maior magnitude em relação às empresas náo beneficiárias quando comparado com os demais setores. No curto prazo, as empresas que recebem crédito com a finalidade capital de giro e custeio geram renda superior às não beneficiárias entre 43,9\% e 64,8\%. Para a finalidade investimento, não se verificam impactos para médias e grandes empresas, no entanto, as micro e pequenas empresas beneficiárias apresentam massa salarial 49,7\% superior às não beneficiárias.

Para o longo prazo, micro e pequenas empresas beneficiárias de crédito para capital de giro e custeio não geram impactos sobre a renda, já as médias e grandes empresas apresentam massa salarial 50,8\% maior que as não beneficiárias. Para a finalidade investimento, as médias e grandes empresas continuam a não apresentar impactos, contudo as micro e pequenas empresas beneficiárias apresentam impacto expressivo $(77,4 \%)$ em relação às não empresas beneficiárias; em outras palavras, para cada $\mathrm{R} \$ 1$ mil pagos em salários pelas micro e pequenas empresas não beneficiárias, as empresas beneficiárias geram entre $\mathrm{R} \$ 1.700,00$ e $\mathrm{R} \$ 1.800,00$, em média, de massa salarial no período após o recebimento do benefício.

Para os setores primário, secundário e terciário reunidos, os resultados em termos de presença de impactos econômicos corroboram com os encontrados para o estoque de emprego. No curto prazo, ou seja, para o ano em que as empresas recebem o recurso proveniente do FNO, os impactos são positivos e significativos para todas as definiçóes de tamanho e de finalidade de crédito. Para capital de giro e custeio, as empresas beneficiárias possuem massa salarial maior que as não beneficiárias entre $12,5 \%$ e $22,7 \%$, já para investimento o intervalo situa-se entre $9,05 \%$ e $12,8 \%$. Portanto, no ano que recebem crédito, as empresas beneficiárias geram renda superior a que teriam gerado caso não tivessem acesso aos recursos provenientes do FNO, ou ainda, para cada $\mathrm{R} \$ 1$ mil gerados ou pagos em salários pelas empresas não beneficiárias, as empresas beneficiárias comparáveis geram entre $\mathrm{R} \$ 1.090,50$ e R\$1.227,00 para a regiáo Norte. 
Tratando-se do curto prazo, não se observaram impactos positivos sobre a geração de renda para médias e grandes empresas no setor primário e no setor terciário quando beneficiárias de crédito para investimento. Nesse caso, não se percebe geração de renda divergente do grupo não beneficiário, ou seja, o crédito não foi determinante para o desempenho destas empresas. A ausência de impactos para essas categorias reforça o resultado obtido na subseção 4.1 de que algumas empresas não enfrentam restriçōes de crédito e mesmo assim acessam os recursos subsidiados.

Quando se considera a trajetória de geração de renda após o recebimento do crédito, apenas as médias e grandes empresas que tiveram capital de giro e custeio financiados não apresentam impactos econômicos. Para as que apresentaram, as micro e pequenas, o impacto econômico foi da ordem de 21,3\% quando comparada às empresas não beneficiárias. Para a finalidade investimento, na região Norte, as empresas beneficiadas pagam massa salarial superior às não beneficiárias em até $33,2 \%$, ou seja, para cada R \$ 1 mil de massa salarial paga por empresas não beneficiárias, o crédito pode potencializar a massa salarial em até $\mathrm{R} \$ 1.332,00$ para a categoria investimento.

Em termos gerais, novamente se observa que, no curto prazo, empresas beneficiárias de crédito para capital de giro e custeio geram impactos superiores sobre a massa salarial quando comparadas a empresas que são beneficiadas com crédito para investimento, no entanto, a lógica se inverte no longo prazo, empresas que receberam crédito para investimento têm trajetória de geração de renda superior às beneficiárias da outra finalidade de crédito. Corroborando com as evidências encontradas para o estoque de emprego, pelo menos no curto prazo, a política do FNO cumpriu com o objetivo de impulsionar a geração de renda na região Norte. No entanto, algumas categorias de crédito e tamanho de empresas não apresentam impactos. Os resultados estão de acordo com os encontrados por Braga et al. (2012). Maior nível de renda na economia potencializa a demanda e o crescimento econômico o que, por sua vez, acaba alimentando o ciclo econômico com maior geração de emprego.

\subsection{Impacto da política de crédito sobre a produtividade média do trabalho}

O comportamento da produtividade média de uma economia revela-se como bom indicador de seu crescimento. Maior produtividade implica maiores salários, esta é a conclusão da teoria microeconômica neoclássica. Por esse motivo, a literatura especializada em avaliaçâo de impacto econômico destaca a utilização do salário médio como uma das variáveis a ser afetada pelos programas e pelas políticas públicas. Um dos objetivos do FNO é impulsionar a produtividade média dos empreendimentos da regiáo Norte.

No setor primário, diferentemente do estoque de emprego e da massa salarial, nenhum dos experimentos (tabela 1) indica presença de impacto econômico 
significativo do FNO sobre o salário médio. Os resultados confirmam a total ausência de impacto do FNO sobre médias e grandes empresas do setor primário independentemente do prazo e da finalidade do crédito e, além disso, que o fato da empresa receber crédito para financiar investimento não gera impactos sobre a trajetória das variáveis de resultados das empresas no setor primário. Assim, é possível sugerir a revisão da política para atender essas categorias de empresas no setor primário. Por sua vez, os resultados também confirmam que os impactos positivos e significativos sobre a massa salarial parecem provir da geração de novos postos de trabalho e não do aumento da produtividade no setor.

Ao contrário do setor primário, no setor secundário, o FNO apresentou impacto sobre alguns experimentos de empresas no longo prazo; já no curto prazo, não é possível identificar impactos das empresas beneficiárias em relação às não beneficiárias com relação ao salário médio. Novamente, os resultados positivos para geração de renda no setor secundário no curto prazo podem ser atribuídos unicamente ao aumento na geração de emprego.

No longo prazo, para empresas beneficiárias do setor secundário, é possível observar impactos positivos e significativos para micro e pequenas empresas (4,33\%) e, consequentemente, para as empresas como um todo $(3,44 \%)$ quando recebem crédito para capital de giro e custeio sobre as não beneficiárias. Em outras palavras, essas empresas passaram a pagar maiores salários médios quando comparadas a empresas não beneficiárias. Isso evidencia que os resultados positivos na geração de renda são resultados tanto do aumento da geração de empregos quanto do aumento da produtividade.

Para as beneficiárias da finalidade investimento, as médias e grandes empresas $(5,22 \%)$ e, em consequência, as empresas sem distinção de tamanho $(2,15 \%)$ pagam melhores salários quando comparadas às não beneficiárias. Essa é a primeira evidência de impacto econômico do FNO no longo prazo sobre médias e grandes empresas do setor primário e secundário. A trajetória de produtividade nessas empresas é alterada no período posterior ao acesso ao crédito em comparação às empresas que não recebem crédito.

No setor terciário, apesar de continuar como o setor onde se identificam os impactos de maior magnitude, não é possível observar, para o curto prazo, qualquer impacto do FNO sobre as empresas beneficiárias. Outra vez, os fortes impactos econômicos positivos percebidos para geração de renda no setor terciário são provocados pelo aumento na geração de novos postos de trabalho e não por aumento da produtividade. Para o longo prazo, na finalidade capital de giro e custeio, não se observam impactos sobre o salário médio de micro e pequenas empresas, assim como não se observavam para massa salarial e estoque de emprego. Contudo, mesmo para médias e grandes empresas, não se observam impactos no salário médio, no 
entanto, ao reunir as empresas, é possível identificar um impacto sobre o salário médio na ordem de 7,13\% em favor de empresas beneficiárias.

Já para a finalidade investimento, apenas micro e pequenas empresas beneficiárias apresentam impactos positivos e significativos na ordem de 9,08\% em relação às não beneficiárias, ou seja, se as empresas não beneficiárias pagam em média $\mathrm{R} \$$ 1 mil, as beneficiárias pagam R \$ 1.009,08, apresentando maior nível médio de produtividade. Tal resultado nos diferentes setores, com relação ao salário médio, pode ser novamente vinculado aos montantes de crédito recebidos e por outros fatores como a configuração típica do setor primário na região.

Para os setores primário, secundário e terciário reunidos, em desacordo com os resultados para estoque de emprego e massa salarial, salvo no longo prazo para médias e grandes empresas beneficiárias de crédito para capital de giro e custeio, o FNO não produz impacto algum sobre a produtividade média, medida pelo salário médio, da economia da região Norte. Nenhum recorte da amostra apresenta impactos positivos e significativos para a variável salário médio.

Em termos gerais, tal resultado reforça a conclusão de que o aumento na renda gerada pelas empresas beneficiárias em relação às não beneficiárias ocorre em função da geração de novos postos de trabalho. Empresas beneficiárias, em geral, não pagam melhores salários quando comparadas às não beneficiárias. Os achados váo ao encontro dos resultados de Silva, Resende e Silveira Neto (2006; 2009) para o FNO no período 2000-2003; contudo, estão em desacordo com os encontrados por Braga et al. (2012) para o FNO no período 2000-2010. A robustez do estimador DD é reconhecida frente aos métodos utilizados pelos trabalhos anteriores, portanto, tornando-os mais consistentes.

É possível afirmar que a política de crédito vinculada ao FNO tem gerado impactos positivos sobre a economia da regiấo Norte na geração de empregos e renda, no entanto, não se identificam impactos em nível satisfatório para aumentos da produtividade do trabalho, ou seja, o FNO, nesse sentido, tem atendido parte de seus objetivos e, de certa forma, os recursos aplicados estão gerando impactos positivos.

\section{CONSIDERAÇÕES FINAIS}

Ao investigar os impactos econômicos sobre estoque de emprego, massa salarial e salário médio promovidos pelas políticas de crédito vinculadas aos fundos constitucionais de financiamento, o presente artigo apresentou evidências de impactos positivos para o FNO entre 2000 e 2010 nas linhas de crédito para investimento e para capital de giro e custeio.

Ao relaxar restrições de crédito de empresas na região Norte, impactos positivos puderam ser observados para diferentes recortes de tamanho das empresas, 
setor econômico e de tempo. Acredita-se que os resultados detalhados neste estudo sejam úteis para o monitoramento da política, bem como para melhoria da gestáo e do desenho dos programas.

O fato de ser beneficiário de alguma das linhas de crédito do programa revelou-se determinante para que a empresa tenha desempenho superior na geraçáo de emprego e renda em relação às empresas não beneficiárias, seja no curto, seja no longo prazo. No entanto, médias e grandes empresas beneficiárias de crédito para financiamento de capital de giro e custeio apresentaram desempenho similar às não beneficiárias no longo prazo quanto à geração de emprego e renda, não apresentando, portanto, impacto de qualquer natureza, tendência também observada sobre o salário médio, independentemente do tamanho, do período e da finalidade de crédito.

Em termos gerais, os impactos positivos observados sobre renda e emprego para a finalidade capital de giro e custeio são maiores no curto prazo em relação ao longo prazo, observando-se o inverso para a finalidade investimento. Além disso, no curto prazo, os impactos percebidos para a finalidade capital de giro e custeio são maiores que os da finalidade investimento, contudo, no longo prazo, a última produz maiores impactos em relação à primeira.

Tais resultados corroboram com a hipótese de que as empresas na regiáo enfrentam restriçóes de crédito assimétricas, ou seja, as empresas beneficiárias de crédito para capital de giro e custeio reduzem mais que proporcionalmente a quantidade de insumos variáveis no curto prazo ao estarem sujeitas a restriçôes de liquidez, já as beneficiárias da finalidade investimento reduziriam mais a utilização de insumos variáveis no longo prazo.

A partir do relaxamento das restriçóes assimétricas, empresas beneficiárias da finalidade capital de giro e custeio apresentam maior impacto sobre emprego e renda no curto prazo em relação à finalidade investimento. Empresas beneficiárias de crédito para investimento promovem acumulação de capital e, no longo prazo, aumentam a produtividade em relaçáo à finalidade capital de giro e custeio e às não beneficiárias apresentando maior impacto sobre emprego e renda.

Para o setor primário, as médias e grandes empresas não apresentam impactos de qualquer natureza em relação às não beneficiárias, evidenciando que elas não enfrentam restriçóes de liquidez mesmo tendo acessado os programas de crédito subsidiado. Beneficiárias da finalidade investimento também não apresentam impactos no longo prazo e, ainda, nenhum impacto pode ser verificado quanto ao salário médio.

No setor secundário, médias e grandes empresas não apresentaram impactos sobre emprego e renda no longo prazo, contudo, impactos positivos foram identificados sobre o salário médio. Impactos positivos sobre o salário médio também 
foram percebidos no setor terciário, que também apresentou os maiores impactos sobre a geração de emprego e renda em relação às empresas não beneficiárias.

Destaca-se, no tocante do acesso ao crédito, que a utilização do estimador de diferenças em diferenças possibilita a obtençâo de resultados consistentes, pois permite o controle de fatores observáveis e não observáveis e, consequentemente, a eliminação do viés promovido pelo problema da autosseleção ao tratamento, comum nesta literatura. Em outras palavras, a técnica permite a comparação entre empresas beneficiárias e não beneficiárias para a avaliação de intervençôes como as políticas de crédito. Como limitaçôes do estudo, é possível ressaltar a não consideraçấo de outras fontes e programas de crédito subsidiado além do ligado ao FNO, além disso, o período de tempo limitado e a exclusão de parte significativa da amostra, devido à limitação das bases de dados, podem introduzir vieses indesejados nas estimaçóes.

Para novas pesquisas, sugere-se a análise de eficiência de diferentes programas públicos sejam de concessão de crédito ou outro. A contribuiçâo do estudo fica clara pelos limites de utilização da política fiscal por parte do governo. Os agentes econômicos perdem bem-estar quando o governo os tributa em busca de recursos que muitas vezes não geram resultados econômicos e sociais satisfatórios. Identificar os impactos positivos e os impactos marginais promovidos pelas políticas é de suma importância no atual cenário de recessão econômica e de retração monetária a que a economia em nível mundial tem experimentado.

\section{REFERÊNCIAS}

ALMEIDA JÚNIOR, M. F.; RESENDE, G. M.; SILVA, A. Distribuição espacial dos fundos constitucionais de financiamento do Nordeste, Norte e Centro-Oeste. Revista de economia, v. 2, ano 31, p. 115-137, 2007.

BASA - BANCO DA AMAZÔNIA. Fundo Constitucional de Financiamento do Norte. Belém: [s.n.], 2012.

BERTRAND, M.; DUFLO, E.; MULLAINATHAN, S. How much we should trust differences-in-differences estimates? NBER Working Paper, n. 8841, 2002.

BLANCARD, S. et al. Short-and long-run credit constraints in french agriculutre: adirectional distance function framework using expenditure-constrined profit functions. American Journal of Agricultural Economics, v. 88, n. 2, p. 351-364, 2006.

BRAGA, M. J. et al. Avaliação de impactos do FNO sobre emprego e salários: Período 2000-2010 - Produto 4. Belém: [s.n.], 2012.

CAMERON, A. C.; TRIVEDI, P. K. Microeconometrics methods and applications. Cambridge: Cambridge University Press, 2005. 1.058 p. 
. Microeconometrics using Stata. Texas: Stata Press. 732 p. 2009.

CIAIAN, P.; FAŁKOWSKI, J.; KANCS, D. Access to credit, factor allocation and farm productivity: Evidence from the CEE transition economies. Agricultural Finance Review, v. 72, n. 1, p. 22-47, 2012.

FÄRE, R.; GROSSKOPF, S.; LEE, H. A nonparametric approach to expenditure-constrained profit maximization. American Journal of Agricultural Economics, v. 72, n. 3, p. 574-581, 1990.

FUNARBE - FUNDAÇÃO ARTHUR BERNARDES. Avaliaçáo dos impactos Do Fundo Constitucional de Financiamento do Norte (FNO) como indutor do desenvolvimento regional: produto 3 parte 1 - modelos de insumo produto e equilíbrio geral. Viçosa: Funarbe, 2012a.

Avaliaçáo dos impactos do Fundo Constitucional de Financiamento do Norte (FNO) como indutor do desenvolvimento regional: produto 3 parte 2 - modelagem econométrica. Viçosa: Funarbe, 2012b.

Avaliaçáo dos impactos do Fundo Constitucional de Financiamento do Norte (FNO) como indutor do desenvolvimento regional: produto 5 modernização da agropecuária e produtividade dos fatores de produção na região Norte. Viçosa: Funarbe, 2012c.

. Efeitos do FNO no desenvolvimento econômico da regiáo Norte: análise de eficácia - produto 6. Viçosa: Funarbe, 2012d.

GERTLER, P. et al. Impact evaluation in practice. Washington, D.C.: The World Bank, 2011.

GUIRKINGER, C.; BOUCHER, S. R. Credit constraints and productivity in Peruvian agriculture. Agricultural Economics, v. 39, p. 295-308, 2008.

IMBENS, G. W.; WOOLDRIDGE, J. M. Recent developments in the econometrics of program evaluation. Journal of Economic Literature, v. 47, n. 1, p. 5-86, 2009.

KHANDKER, S.; KOOLWAL, G.; SAMAD, H. Handbook on impact evaluation: Quantitative methods ans practices. Washington, D.C.: The World Bank, 2009.

LEE, H.; CHAMBERS, R. G. Expenditure constraints and profit maximization in U.S. agriculture. American Journal of Agricultural Economics, v. 68, n. 4, p. 857-865, 1986.

MISHRA, A. K.; MOSS, C. B.; ERICKSON, K. W. The role of credit constraints and government subsidies in farmland valuations in the US: an options pricing model approach. Empirical Economics, v. 34, n. 2, p. 285-297, 2008. 
MODIGLIANI, F.; MILLER, M. The cost of capital, corporation finance and the theory of investment. The American Economic Review, v. 48, n. 3, p. 261 297, 1958.

OLIVEIRA, G. R.; MENEZES, R. T.; RESENDE, G. M. Efeito dose resposta do Fundo Constitucional de Financiamento do Centro-Oeste (FCO) no estado de Goiás. Brasília: Ipea, 2015. (Texto para Discussão, n. 2133).

OLIVEIRA, H. C.; DOMINGUES, E. P. Considerações sobre o impacto dos fundos constitucionais de financiamento do Norte e do Centro-Oeste na reduçáo da desigualdade regional no Brasil. In: ENCONTRO NACIONAL DE ECONOMIA, 33., Natal, Rio Grande do Norte, 2005. Anais... Natal: Anpec, 2005.

RESENDE, G. M. Avaliaçáo dos impactos econômicos do Fundo Constitucional de Financiamento do Nordeste entre 2004 e 2010. Brasília: Ipea, 2014 a. (Texto para Discussão, n. 1918).

Avaliaçáo dos impactos regionais do Fundo Constitucional de Financiamento do Norte entre 2004 e 2010. Brasília: Ipea, 2014b. (Texto para Discussão, n. 1973).

RESENDE, G. M.; CRAVO, T. A.; PIRES, M. J. S. Avaliaçáo dos impactos econômicos do Fundo Constitucional de Financiamento do Centro- entre 2004 e 2010. Brasília: Ipea, 2014. (Texto para Discussão, n. 1969).

RESENDE, G. M.; SILVA, D. F. C.; SILVA FILHO, L. A. Avaliaçáo dos efeitos econômicos dos Fundos Constitucionais de Financiamento do Nordeste, do Norte e do Centro-Oeste: uma análise por tipologia da Política Nacional de Desenvolvimento Regional entre 1999 e 2011. Brasília: Ipea, 2015. (Texto para Discussão, n. 2145).

SANTOS, R. B. Impactos da restriçáo ao crédito rural nos estabelecimentos agropecuários brasileiros. 2010. 143 p. Tese (Doutorado em Economia Aplicada) Departamento de Economia Rural, Universidade Federal de Viçosa, Viçosa, 2010.

SEBRAE - SERVIÇO BRASILEIRO DE APOIO ÀS MICRO E PEQUENAS EMPRESAS; DIEESE - DEPARTAMENTO INTERSINDICAL DE ESTATÍSTICA E ESTUDOS SOCIOECONÔMICOS. Anuário do trabalho na micro e pequena empresa. 6. Ed. Brasília: Sebrae, 2013. 288 p.

SILVA, M. A.; RESENDE, G.; SILVEIRA NETO, R. M. Avaliaçáo econômica dos fundos constitucionais de financiamento do Nordeste (FNE) e do Norte (FNO). Brasília: Ipea, 2006. (Texto para Discussão, n. 1207). . Eficácia do gasto público: uma avaliação do FNE, FNO e FCO. Estudos Econômicos, São Paulo, v. 39, n. 1, p. 89-125, 2009. 
SOARES, R. B. et al. Avaliaçóes de impacto e eficiência das empresas beneficiadas pelo FNE: geração de emprego, massa salarial e salário médio 2000-2008. Fortaleza: BNB, 2013. (Série Avaliação de Políticas e Programas do BNB).

SOUSA, J.; NOTTINGHAM, P.; GONÇALVES, M. Metodologia de avaliaçáo do Fundo Constitucional de Financiamento do Nordeste (FNE). Fortaleza: [s.n.], 2010. Disponível em: <https://bit.ly/3lgZmg8>. Acesso em: 26 mar. 2014.

\section{BIBLIOGRAFIA COMPLEMENTAR}

IBGE - INSTITUTO BRASILEIRO DE GEOGRAFIA E ESTATÍSTICA. Contas regionais de 2013. [s.l.]: IBGE, 2013. Disponível em: <http://www.ibge. gov.br>. Acesso em: 20 nov. 2015. 
APÊNDICE A

RESULTADOS DO PROCEDIMENTO DE DIFERENÇAS EM DIFERENÇAS

TABELA A. 1

Impacto sobre o estoque de emprego no setor primário

\begin{tabular}{|c|c|c|c|c|c|c|}
\hline Variáveis & $\mathrm{MP} / \mathrm{CP}$ & $M P / L P$ & $\mathrm{MG} / \mathrm{CP}$ & $\mathrm{MG} / \mathrm{LP}$ & $\mathrm{ALL} / \mathrm{CP}$ & ALL/LP \\
\hline Ano de acesso (giro e custeio) & $0,195^{* *}$ & & $-0,0443$ & & $0,138^{*}$ & \\
\hline Ano de acesso (investimento) & $0,155^{* *}$ & & 0,0207 & & $0,123^{*}$ & \\
\hline Anos após acesso (giro e custeio) & & $0,350^{* * *}$ & & $-0,106$ & & $0,227^{*}$ \\
\hline Anos após acesso (investimento) & & 0,101 & & 0,0627 & & 0,0617 \\
\hline PIB per capita & $-0,000189$ & $-0,000185$ & $0,0107^{* *}$ & $0,0105^{* *}$ & $-0,0000131$ & $-0,0000123$ \\
\hline Tocantins & $-0,299^{* * *}$ & $-0,299 * * *$ & - & - & $-0,297^{* * *}$ & $-0,297^{* * *}$ \\
\hline Roraima & - & - & - & - & - & - \\
\hline Rondônia & $-0,0920$ & $-0,0922$ & - & - & - & - \\
\hline Amapá & $-0,132$ & $-0,131$ & - & - & $-0,130$ & $-0,129$ \\
\hline Amazonas & - & - & - & - & 0,0899 & 0,0900 \\
\hline Acre & 0,0195 & 0,0194 & - & - & 0,113 & 0,113 \\
\hline Proporção de funcionários analfabetos & $0,00375^{* *}$ & $0,00374^{* *}$ & 0,0976 & 0,0986 & $0,00380^{* *}$ & $0,00380^{* *}$ \\
\hline Proporção com fundamental incompleto & $0,00372^{* *}$ & $0,00371^{* *}$ & 0,0983 & 0,0993 & $0,00377^{* *}$ & $0,00376^{* *}$ \\
\hline Proporção com fundamental completo & $0,00370^{* *}$ & $0,00370^{* *}$ & 0,0978 & 0,0988 & $0,00375^{* *}$ & $0,00375^{* *}$ \\
\hline Proporção com ensino médio & $0,00394^{* *}$ & $0,00394^{* *}$ & 0,0959 & 0,0969 & $0,00397^{* *}$ & $0,00397^{* *}$ \\
\hline Proporção com ensino superior & 0,00170 & 0,00167 & 0,0959 & 0,0967 & 0,00149 & 0,00148 \\
\hline Proporção com pós-graduação & 0,00283 & 0,00283 & $-0,0370$ & $-0,0367$ & 0,00266 & 0,00266 \\
\hline Tendência linear & $0,0259^{* * *}$ & $0,0257^{* * *}$ & $0,0332^{* * *}$ & $0,0342^{* * *}$ & $0,0254^{* * *}$ & $0,0252^{* * *}$ \\
\hline 2000 (ano) & - & - & - & - & - & - \\
\hline 2001 (ano) & 0,00191 & 0,00143 & $0,104^{* *}$ & $0,106^{* *}$ & 0,00201 & 0,00169 \\
\hline 2002 (ano) & $0,0301^{* * *}$ & $0,0296 * * *$ & $0,125^{* *}$ & $0,127^{* *}$ & $0,0310^{* * *}$ & $0,0306^{* * *}$ \\
\hline 2003 (ano) & $0,0679 * * *$ & $0,0673^{* * *}$ & 0,0562 & 0,0591 & $0,0672^{* * *}$ & $0,0668^{* * *}$ \\
\hline 2004 (ano) & $0,118^{* * *}$ & $0,117^{* * *}$ & $0,0943^{* *}$ & $0,0971^{* *}$ & $0,117^{* * *}$ & $0,116^{* * *}$ \\
\hline 2005 (ano) & $0,0888^{* * *}$ & $0,0883^{* * *}$ & 0,0760 & 0,0784 & $0,0871^{* * *}$ & $0,0868^{* * *}$ \\
\hline 2006 (ano) & $0,0566^{* * *}$ & $0,0562^{* * *}$ & 0,0206 & 0,0237 & $0,0572^{* * *}$ & $0,0569^{* * *}$ \\
\hline 2007 (ano) & $0,0492^{* * *}$ & $0,0490 * * *$ & 0,0387 & 0,0407 & $0,0495 * * *$ & $0,0495 * * *$ \\
\hline 2008 (ano) & $0,0255^{* * *}$ & $0,0255^{* * *}$ & $0,0691^{*}$ & $0,0701^{*}$ & $0,0271^{* * *}$ & $0,0271^{* * *}$ \\
\hline 2009 (ano) & $0,00924^{* *}$ & $0,00925^{* *}$ & 0,0319 & 0,0320 & $0,00978^{* *}$ & 0,00979 ** \\
\hline 2010 (ano) & - & - & - & - & - & - \\
\hline Micro ou pequena empresa & & & & & - & - \\
\hline Média empresa & & & & & $1,224^{* * *}$ & $1,226^{* * *}$ \\
\hline Grande empresa & & & & & $2,181^{* * *}$ & $2,174^{* * *}$ \\
\hline Constante & $-51,52^{* * *}$ & $-50,99 * * *$ & $-71,80^{* * *}$ & $-73,94^{* * *}$ & $-50,48^{* * *}$ & $-50,09 * * *$ \\
\hline Observações & 120.006 & 120.006 & 1.216 & 1.216 & 121.222 & 121222 \\
\hline$R^{2}$ & 0,021 & 0,021 & 0,088 & 0,089 & 0,057 & 0,057 \\
\hline$R^{2}$ Ajustado & 0,021 & 0,021 & 0,073 & 0,074 & 0,057 & 0,057 \\
\hline
\end{tabular}

Fonte: Resultados da pesquisa.

Elaboração dos autores.

Obs.: 1. MP = micro e pequenas empresas; $M G$ = médias e grandes empresas; $\mathrm{ALL}=$ todas as empresas; $\mathrm{CP}=$ curto prazo, igual a 1 para 0 ano de tratamento; $\mathrm{LP}=$ longo prazo, igual a 1 para os anos após 0 tratamento.

2. ${ }^{*} p<0.10$; ${ }^{* *} p<0.05 ;{ }^{* * *} p<0.01$.

3. (-) omitido devido à colinearidade. 
TABELA A.2

Impacto sobre o estoque de emprego no setor secundário

\begin{tabular}{|c|c|c|c|c|c|c|}
\hline Variáveis & $\mathrm{MP} / \mathrm{CP}$ & $M P / L P$ & $\mathrm{MG} / \mathrm{CP}$ & MG/LP & ALL/CP & ALL/LP \\
\hline Ano de acesso (giro e custeio) & $0,227^{\star * *}$ & & $0,140^{* * *}$ & & $0,185^{* * *}$ & \\
\hline Ano de acesso (investimento) & $0,0554^{* *}$ & & $0,0841^{* *}$ & & $0,0760^{* * *}$ & \\
\hline Anos após acesso (giro e custeio) & & $0,215^{* * *}$ & & $-0,0472$ & & $0,161^{* * *}$ \\
\hline Anos após acesso (investimento) & & $0,362^{* * *}$ & & 0,0367 & & $0,327^{* * *}$ \\
\hline PIB per capita & $0,00833^{* * *}$ & $0,00822^{* * *}$ & 0,00796 & 0,00784 & $0,00902^{* * *}$ & $0,00891^{* * *}$ \\
\hline Tocantins & $-0,161$ & $-0,159$ & $0,717^{* * *}$ & $0,717^{* * *}$ & $-0,0156$ & $-0,0203$ \\
\hline Roraima & $-1,094$ & $-1,099$ & - & - & $-0,672$ & $-0,684$ \\
\hline Rondônia & $-1,395$ & $-1,396$ & $1,065^{* * *}$ & $1,070^{* * *}$ & $-0,974$ & $-0,982$ \\
\hline Amapá & $-0,754$ & $-0,795$ & - & - & $-0,796$ & $-0,830$ \\
\hline Amazonas & $-0,810$ & $-0,806$ & - & - & $-0,394$ & $-0,397$ \\
\hline Acre & - & - & - & - & - & - \\
\hline Proporção de funcionários analfabetos & $-0,00220$ & $-0,00238$ & $0,120^{* * *}$ & $0,115^{* *}$ & $-0,00184$ & $-0,00178$ \\
\hline Proporção com fundamental incompleto & $-0,00199$ & $-0,00216$ & $0,120^{* * *}$ & $0,116^{* *}$ & $-0,00168$ & $-0,00161$ \\
\hline Proporção com fundamental completo & $-0,00192$ & $-0,00208$ & $0,118^{* * *}$ & $0,114^{* *}$ & $-0,00159$ & $-0,00151$ \\
\hline Proporção com ensino médio & $-0,00224$ & $-0,00241$ & $0,124^{* * *}$ & $0,120 * * *$ & $-0,00193$ & $-0,00186$ \\
\hline Proporção com ensino superior & $-0,00823$ & $-0,00839$ & $0,117^{* * *}$ & $0,112^{* *}$ & $-0,00965^{*}$ & $-0,00958^{*}$ \\
\hline Proporção com pós-graduação & $-0,00257$ & $-0,00274$ & 0,0118 & 0,00272 & $-0,00296$ & $-0,00303$ \\
\hline Tendência linear & $-0,00809^{* * *}$ & $-0,0109 * * *$ & $0,0422^{* * *}$ & $0,0420 * * *$ & $-0,00914^{* * *}$ & $-0,0119 * * *$ \\
\hline 2000 (ano) & - & - & - & - & - & - \\
\hline 2001 (ano) & $-0,0172$ & $-0,0177$ & $-0,0739 * * *$ & $-0,0717^{* * *}$ & $-0,0200^{*}$ & $-0,0208^{* *}$ \\
\hline 2002 (ano) & $-0,0104$ & $-0,0101$ & $-0,0469^{* *}$ & $-0,0447^{*}$ & $-0,0128$ & $-0,0131$ \\
\hline 2003 (ano) & $-0,0306^{* *}$ & $-0,0296$ ** & $-0,0294$ & $-0,0270$ & $-0,0293^{* *}$ & $-0,0290$ ** \\
\hline 2004 (ano) & 0,00792 & 0,00891 & 0,00725 & 0,00938 & 0,00539 & 0,00576 \\
\hline 2005 (ano) & $-0,00855$ & $-0,00751$ & $-0,00486$ & $-0,00732$ & $-0,0102$ & $-0,00979$ \\
\hline 2006 (ano) & $-0,0210^{*}$ & $-0,0195$ & 0,0283 & 0,0259 & $-0,0224^{*}$ & $-0,0216^{*}$ \\
\hline 2007 (ano) & $-0,00652$ & $-0,00492$ & $0,0498^{* *}$ & $0,0477^{* *}$ & $-0,00641$ & $-0,00530$ \\
\hline 2008 (ano) & $-0,0414^{* * *}$ & $-0,0398^{* * *}$ & $-0,0109$ & $-0,0115$ & $-0,0412^{* * *}$ & $-0,0400^{* * *}$ \\
\hline 2009 (ano) & $-0,0483^{* * *}$ & $-0,0470^{* * *}$ & $-0,0434^{* * *}$ & $-0,0414^{* * *}$ & $-0,0465^{* * *}$ & $-0,0456^{* * *}$ \\
\hline 2010 (ano) & - & - & - & - & - & - \\
\hline Micro ou pequena empresa & & & & & $-2,441 * * *$ & $-2,414^{* * *}$ \\
\hline Média empresa & & & & & $-0,974^{* * *}$ & $-0,952^{* * *}$ \\
\hline Grande empresa & & & & & - & - \\
\hline Constante & $18,71^{\star \star *}$ & $24,29 * * *$ & $-91,49 * * *$ & $-90,69^{* * *}$ & $23,16^{\star \star \star}$ & $28,62^{* * *}$ \\
\hline Observações & 68.004 & 68.004 & 3.835 & 3.835 & 71.839 & 71.839 \\
\hline$R^{2}$ & 0,006 & 0,009 & 0,220 & 0,218 & 0,092 & 0,095 \\
\hline$R^{2}$ Ajustado & 0,005 & 0,008 & 0,216 & 0,213 & 0,092 & 0,094 \\
\hline
\end{tabular}

Fonte: Resultados da pesquisa.

Elaboração dos autores.

Obs.: 1. MP = micro e pequenas empresas; $M G=$ médias e grandes empresas; $A L L=$ todas as empresas; $C P=$ curto prazo, igual a 1 para 0 ano de tratamento; LP = longo prazo, igual a 1 para os anos após o tratamento.

2. ${ }^{*} p<0.10 ;{ }^{* *} p<0.05 ;{ }^{* * *} p<0.01$.

3. (-) omitido devido à colinearidade. 
TABELA A.3

Impacto sobre o estoque de emprego no setor terciário

\begin{tabular}{|c|c|c|c|c|c|c|}
\hline Variáveis & $\mathrm{MP} / \mathrm{CP}$ & MP/LP & $\mathrm{MG} / \mathrm{CP}$ & $M G / L P$ & ALL/CP & ALL/LP \\
\hline Ano de acesso (giro e custeio) & $0,653^{* * *}$ & & $0,378^{* *}$ & & $0,587^{* * *}$ & \\
\hline Ano de acesso (investimento) & $0,478^{* * *}$ & & $0,198^{* *}$ & & $0,374^{* * *}$ & \\
\hline Anos após acesso (giro e custeio) & & 0,339 & & $0,418^{* * *}$ & & $0,425^{* *}$ \\
\hline Anos após acesso (investimento) & & $0,695 * * *$ & & $0,174^{* *}$ & & $0,487^{\star * *}$ \\
\hline PIB per capita & 0,00566 ** & 0,00561 ** & $0,00409^{* *}$ & 0,00420 ** & $0,00384^{* *}$ & $0,00388^{* *}$ \\
\hline Tocantins & $-0,622$ & $-0,624$ & 0,0189 & 0,0221 & $-0,332$ & $-0,332$ \\
\hline Roraima & 0,456 & 0,458 & $0,234^{* * *}$ & $0,243^{* * *}$ & 0,541 & 0,545 \\
\hline Rondônia & $-0,0184$ & $-0,0198$ & 0,188 & 0,194 & 0,182 & 0,181 \\
\hline Amapá & 0,672 & $0,746^{*}$ & - & - & $0,702^{*}$ & $0,752^{*}$ \\
\hline Amazonas & $-0,321$ & $-0,323$ & $0,426^{* * *}$ & $0,431^{* * *}$ & $-0,0478$ & $-0,0482$ \\
\hline Acre & $-0,645$ & $-0,641$ & - & - & $-0,0688$ & $-0,0696$ \\
\hline Proporção de funcionários analfabetos & $0,00945^{* * *}$ & $0,00961^{* * *}$ & $-0,0651^{* * *}$ & $-0,0658^{* * *}$ & $0,00765^{* * *}$ & $0,00765^{* * *}$ \\
\hline Proporção com fundamental incompleto & $0,0113^{* * *}$ & $0,0113^{* * *}$ & $-0,0612^{* * *}$ & $-0,0618^{* * *}$ & $0,0101 * * *$ & $0,0100 * * *$ \\
\hline Proporção com fundamental completo & $0,0100 * * *$ & $0,0101 * * *$ & $-0,0593^{\star *}$ & $-0,0598^{* *}$ & $0,00900 * * *$ & $0,00891^{* * *}$ \\
\hline Proporção com ensino médio & $0,00629^{* * *}$ & $0,00634^{* * *}$ & $-0,0639 * * *$ & $-0,0646^{* * *}$ & $0,00513^{* *}$ & $0,00503^{* *}$ \\
\hline Proporção com ensino superior & 0,00104 & 0,00109 & $-0,0754^{* * *}$ & $-0,0760 * * *$ & $-0,000906$ & $-0,00101$ \\
\hline Proporção com pós-graduação & 0,00692 & 0,00682 & $-0,0690 * * *$ & $-0,0691 * * *$ & 0,00526 & 0,00510 \\
\hline Tendência linear & $0,0241 * * *$ & $0,0224^{* * *}$ & $0,0505^{* * *}$ & $0,0491 * * *$ & $0,0195^{* * *}$ & $0,0180 * * *$ \\
\hline 2000 (ano) & - & - & - & - & - & - \\
\hline 2001 (ano) & 0,0232 & 0,0236 & $-0,0370$ & $-0,0361$ & 0,0156 & 0,0161 \\
\hline 2002 (ano) & $-0,0172$ & $-0,0167$ & $-0,117^{\star \star *}$ & $-0,113^{* * *}$ & $-0,0285$ & $-0,0270$ \\
\hline 2003 (ano) & $-0,0861 * * *$ & $-0,0862 * * *$ & $-0,205^{* * *}$ & $-0,202 * * *$ & $-0,0951^{\text {***}}$ & $-0,0940^{* * *}$ \\
\hline 2004 (ano) & $-0,139 * * *$ & $-0,139 * * *$ & $-0,161^{* * *}$ & $-0,157^{* * *}$ & $-0,140$ *** & $-0,139^{* * *}$ \\
\hline 2005 (ano) & $-0,124^{* * *}$ & $-0,122^{* * *}$ & $-0,162^{* * *}$ & $-0,158^{* * *}$ & $-0,129 * * *$ & $-0,127^{* * *}$ \\
\hline 2006 (ano) & $-0,0904^{* * *}$ & $-0,0859 * * *$ & $-0,113^{\star * *}$ & $-0,106^{* * *}$ & $-0,0869 * * *$ & $-0,0825 * * *$ \\
\hline 2007 (ano) & $-0,0782^{\star * *}$ & $-0,0739 * * *$ & $-0,00495$ & 0,000465 & $-0,0690^{* * *}$ & $-0,0647^{* * *}$ \\
\hline 2008 (ano) & $-0,0295$ & $-0,0248$ & $-0,0523^{*}$ & $-0,0480$ & $-0,0373^{* *}$ & $-0,0330^{*}$ \\
\hline 2009 (ano) & $-0,0201$ & $-0,0170$ & $-0,0164$ & $-0,0130$ & $-0,0180$ & $-0,0153$ \\
\hline 2010 (ano) & - & - & - & - & - & - \\
\hline Micro ou pequena empresa & & & & & $-2,327^{* * *}$ & $-2,320 * * *$ \\
\hline Média empresa & & & & & $-0,855^{* * *}$ & $-0,850$ *** \\
\hline Grande empresa & & & & & - & - \\
\hline Constante & $-47,60^{* * *}$ & $-44,18^{* * *}$ & $-90,32^{* * *}$ & $-87,39 * * *$ & $-35,96^{* * *}$ & $-32,85^{* * *}$ \\
\hline Observações & 32.484 & 32.484 & 3.750 & 3.750 & 36.234 & 36.234 \\
\hline$R^{2}$ & 0,041 & 0,042 & 0,155 & 0,156 & 0,263 & 0,264 \\
\hline$R^{2}$ Ajustado & 0,040 & 0,042 & 0,150 & 0,151 & 0,262 & 0,263 \\
\hline
\end{tabular}

Fonte: Resultados da pesquisa.

Elaboração dos autores.

Obs.: 1. MP = micro e pequenas empresas; $M G=$ médias e grandes empresas; $A L L=$ todas as empresas; $C P=$ curto prazo, igual a 1 para 0 ano de tratamento; $L P=$ longo prazo, igual a 1 para os anos após o tratamento.

2. ${ }^{*} p<0.10 ;{ }^{* *} p<0.05 ;{ }^{* * *} p<0.01$.

3. (-) omitido devido à colinearidade. 
TABELA A.4

Impacto sobre o estoque de emprego na economia da região Norte

\begin{tabular}{|c|c|c|c|c|c|c|}
\hline Variáveis & $\mathrm{MP} / \mathrm{CP}$ & MP/LP & $\mathrm{MG} / \mathrm{CP}$ & $M G / L P$ & $\mathrm{ALL} / \mathrm{CP}$ & ALL/LP \\
\hline Ano de acesso (giro e custeio) & $0,231^{* * *}$ & & $0,121^{* *}$ & & $0,191^{* * *}$ & \\
\hline Ano de acesso (investimento) & $0,130^{* * *}$ & & $0,111^{* * *}$ & & $0,133^{* * *}$ & \\
\hline Anos após acesso (giro e custeio) & & $0,196^{* * *}$ & & $-0,0274$ & & $0,144^{* * *}$ \\
\hline Anos após acesso (investimento) & & $0,333^{* * *}$ & & $0,0989^{* *}$ & & $0,280^{* * *}$ \\
\hline PIB per capita & $0,00341^{* * *}$ & $0,00336^{* * *}$ & $0,00625^{* * *}$ & $0,00622^{* * *}$ & $0,00343^{* * *}$ & $0,00337^{* * *}$ \\
\hline Setor primário & - & - & $-0,147^{* *}$ & $-0,130$ & - & - \\
\hline Setor secundário & $0,185^{* * *}$ & $0,182^{* * *}$ & - & 0,0119 & $0,240^{* * *}$ & $0,238^{* * *}$ \\
\hline Setor terciário & 0,0796 & 0,0788 & $-0,0167$ & - & $0,0866^{*}$ & 0,0859 * \\
\hline Tocantins & $-0,315^{* *}$ & $-0,316^{* *}$ & 0,345 & 0,347 & $-0,232^{*}$ & $-0,233^{*}$ \\
\hline Roraima & 0,0680 & 0,0672 & $0,360^{* * *}$ & $0,361^{* * *}$ & 0,339 & 0,340 \\
\hline Rondônia & $-0,542$ & $-0,543$ & $0,501^{* *}$ & $0,502^{* *}$ & $-0,250$ & $-0,253$ \\
\hline Amapá & 0,209 & 0,228 & - & - & 0,223 & 0,239 \\
\hline Amazonas & $-0,496$ & $-0,496$ & $0,464^{* * *}$ & $0,464^{* * *}$ & $-0,178$ & $-0,178$ \\
\hline Acre & $-0,475$ & $-0,476$ & - & - & $-0,173$ & $-0,177$ \\
\hline Proporção de funcionários analfabetos & $0,00409^{* * *}$ & $0,00408^{* * *}$ & 0,0114 & 0,00906 & $0,00396^{* *}$ & $0,00397^{* *}$ \\
\hline Proporção com fundamental incompleto & $0,00420 * * *$ & $0,00419^{* * *}$ & 0,0134 & 0,0111 & $0,00409^{* *}$ & $0,00411^{* *}$ \\
\hline Proporção com fundamental completo & $0,00420^{* * *}$ & $0,00419^{* * *}$ & 0,0139 & 0,0115 & $0,00411^{* *}$ & $0,00413^{* *}$ \\
\hline Proporção com ensino médio & $0,00329^{* *}$ & $0,00327^{* *}$ & 0,0134 & 0,0111 & $0,00313^{*}$ & $0,00313^{*}$ \\
\hline Proporção com ensino superior & $-0,00191$ & $-0,00193$ & 0,00532 & 0,00301 & $-0,00310^{*}$ & $-0,00310^{*}$ \\
\hline Proporção com pós-graduação & 0,00340 & 0,00336 & $-0,00359$ & $-0,00584$ & 0,00294 & 0,00289 \\
\hline Tendência linear & $0,0137^{* * *}$ & $0,0126^{* * *}$ & $0,0462^{* * *}$ & $0,0452^{* * *}$ & $0,0123^{* * *}$ & $0,0112^{* * *}$ \\
\hline 2000 (ano) & - & - & - & - & - & - \\
\hline 2001 (ano) & $-0,00558$ & $-0,00665$ & $-0,0401^{* *}$ & $-0,0389^{* *}$ & $-0,00792$ & $-0,00888$ \\
\hline 2002 (ano) & 0,00112 & 0,0000661 & $-0,0559 * * *$ & $-0,0547^{* * *}$ & $-0,00258$ & $-0,00358$ \\
\hline 2003 (ano) & 0,000709 & $-0,000369$ & $-0,0774^{* * *}$ & $-0,0762^{* * *}$ & $-0,00366$ & $-0,00471$ \\
\hline 2004 (ano) & $0,0373^{* * *}$ & $0,0362^{* * *}$ & $-0,0363^{*}$ & $-0,0354^{*}$ & $0,0307^{* * *}$ & 0,0296 *** \\
\hline 2005 (ano) & $0,0191^{* * *}$ & $0,0182^{* * *}$ & $-0,0433^{* *}$ & $-0,0443^{* *}$ & $0,0125^{\star *}$ & $0,0116^{*}$ \\
\hline 2006 (ano) & 0,00279 & 0,00225 & $-0,0205$ & $-0,0210$ & $-0,000457$ & $-0,00103$ \\
\hline 2007 (ano) & 0,00658 & 0,00648 & $0,0352^{*}$ & $0,0350^{*}$ & 0,00511 & 0,00498 \\
\hline 2008 (ano) & $-0,00803$ & $-0,00778$ & $-0,00832$ & $-0,00745$ & $-0,00979^{* *}$ & $-0,00959^{* *}$ \\
\hline 2009 (ano) & $-0,0149 * * *$ & $-0,0147^{* * *}$ & $-0,0161$ & $-0,0148$ & $-0,0144^{* * *}$ & $-0,0143^{* * *}$ \\
\hline 2010 (ano) & - & - & - & - & - & - \\
\hline Micro ou pequena empresa & & & & & $-2,333^{* * *}$ & $-2,323^{* * *}$ \\
\hline Média empresa & & & & & $-0,892^{* * *}$ & $-0,886^{* * *}$ \\
\hline Grande empresa & & & & & - & - \\
\hline Constante & $-26,54^{* * *}$ & $-24,22^{* * *}$ & $-89,02^{* * *}$ & $-86,92^{* * *}$ & $-21,33^{* * *}$ & $-19,13^{* * *}$ \\
\hline Observações & 220.494 & 220.494 & 8.801 & 8.801 & 229.295 & 229.295 \\
\hline$R^{2}$ & 0,009 & 0,010 & 0,146 & 0,145 & 0,119 & 0,120 \\
\hline$R^{2}$ Ajustado & 0,009 & 0,010 & 0,144 & 0,143 & 0,119 & 0,120 \\
\hline
\end{tabular}

Fonte: Resultados da pesquisa.

Elaboração dos autores.

Obs.: 1. MP = micro e pequenas empresas; $M G=$ médias e grandes empresas; $A L L=$ todas as empresas; $C P=$ curto prazo, igual a 1 para 0 ano de tratamento; $L P=$ longo prazo, igual a 1 para os anos após o tratamento.

2. ${ }^{*} p<0.10 ;{ }^{* *} p<0.05 ;{ }^{* * *} p<0.01$.

3. (-) omitido devido à colinearidade. 
TABELA A. 5

Impacto sobre a massa salarial no setor primário

\begin{tabular}{|c|c|c|c|c|c|c|}
\hline Variáveis & $\mathrm{MP} / \mathrm{CP}$ & MP/LP & $\mathrm{MG} / \mathrm{CP}$ & $M G / L P$ & ALL/CP & $A L L / L P$ \\
\hline Ano de acesso (giro e custeio) & $0,200 * * *$ & & $-0,0105$ & & $0,144^{* *}$ & \\
\hline Ano de acesso (investimento) & $0,147^{* *}$ & & 0,0406 & & $0,128^{*}$ & \\
\hline Anos após acesso (giro e custeio) & & $0,312^{* * *}$ & & $-0,0824$ & & $0,190^{*}$ \\
\hline Anos após acesso (investimento) & & 0,0767 & & 0,164 & & 0,0620 \\
\hline PIB per capita & 0,000155 & 0,000159 & $0,0151^{* * *}$ & $0,0149 * * *$ & 0,000418 & 0,000417 \\
\hline Tocantins & $-0,343^{* * *}$ & $-0,343^{* * *}$ & - & - & $-0,342^{* * *}$ & $-0,342^{* * *}$ \\
\hline Roraima & - & - & - & - & - & - \\
\hline Rondônia & 0,0500 & 0,0498 & - & - & 0,0501 & 0,0500 \\
\hline Amapá & $-0,0991$ & $-0,0983$ & - & - & $-0,0966$ & $-0,0959$ \\
\hline Amazonas & - & - & - & - & - & - \\
\hline Acre & 0,121 & 0,121 & - & - & 0,123 & 0,123 \\
\hline Proporção de funcionários analfabetos & $0,00363^{*}$ & $0,00363^{*}$ & 0,0162 & 0,0147 & $0,00364^{*}$ & $0,00364^{*}$ \\
\hline Proporção com fundamental incompleto & $0,00388^{* *}$ & $0,00388^{* *}$ & 0,0176 & 0,0161 & $0,00389^{* *}$ & $0,00388^{* *}$ \\
\hline Proporção com fundamental completo & 0,00395 ** & $0,00394^{* *}$ & 0,0166 & 0,0150 & 0,00396 ** & $0,00395^{* *}$ \\
\hline Proporção com ensino médio & $0,00457^{\star *}$ & $0,00456^{* *}$ & 0,0168 & 0,0152 & $0,00457^{\star *}$ & $0,00456^{* *}$ \\
\hline Proporção com ensino superior & $0,00687^{* * *}$ & $0,00685^{* * *}$ & 0,0252 & 0,0235 & $0,00687^{\star * *}$ & $0,00686^{* * *}$ \\
\hline Proporção com pós-graduação & 0,00180 & 0,00180 & $-0,113$ & $-0,114$ & 0,00161 & 0,00161 \\
\hline Tendência linear & $0,0842^{* * *}$ & $0,0840^{* * *}$ & $0,0739 * * *$ & $0,0745^{* * *}$ & $0,0835^{* * *}$ & $0,0833^{* * *}$ \\
\hline 2000 (ano) & - & - & - & - & - & - \\
\hline 2001 (ano) & 0,00751 & 0,00706 & 0,0888 & $0,0930^{*}$ & 0,00777 & 0,00745 \\
\hline 2002 (ano) & $-0,0425^{* * *}$ & $-0,0430$ *** & $-0,00957$ & $-0,00630$ & $-0,0420^{* * *}$ & $-0,0423^{* * *}$ \\
\hline 2003 (ano) & 0,0136 & 0,0131 & $-0,0607$ & $-0,0562$ & 0,0124 & 0,0120 \\
\hline 2004 (ano) & $0,0421^{* * *}$ & $0,0416^{* * *}$ & $-0,0122$ & $-0,00805$ & $0,0405^{* * *}$ & $0,0402^{* * *}$ \\
\hline 2005 (ano) & $0,0571^{* * *}$ & $0,0567^{* * *}$ & $-0,0106$ & $-0,00705$ & $0,0548^{* * *}$ & $0,0545^{* * *}$ \\
\hline 2006 (ano) & $0,0706^{* * *}$ & $0,0702^{* * *}$ & $-0,0115$ & $-0,00661$ & $0,0702^{* * *}$ & $0,0699^{* * *}$ \\
\hline 2007 (ano) & $0,0430 * * *$ & $0,0429 * * *$ & 0,00285 & 0,00672 & $0,0428^{* * *}$ & $0,0427^{* * *}$ \\
\hline 2008 (ano) & $0,0147^{* * *}$ & $0,0147^{* * *}$ & 0,0413 & 0,0422 & $0,0159 * * *$ & $0,0159^{* * *}$ \\
\hline 2009 (ano) & $0,0196 * * *$ & $0,0196^{* * *}$ & 0,0352 & 0,0355 & $0,0197^{* * *}$ & $0,0197^{* * *}$ \\
\hline 2010 (ano) & - & - & - & - & - & - \\
\hline Micro ou pequena empresa & & & & & - & - \\
\hline Média empresa & & & & & $1,110^{* * *}$ & $1,111^{* * *}$ \\
\hline Grande empresa & & & & & $2,018^{* * *}$ & $2,011^{* * *}$ \\
\hline Constante & $-162,1^{\star * *}$ & $-161,7^{* * *}$ & $-138,6^{* * *}$ & $-139,7^{* * *}$ & $-160,7^{* * *}$ & $-160,4^{* * *}$ \\
\hline Observações & 118.204 & 118.204 & 1.215 & 1.215 & 119.419 & 119.419 \\
\hline$R^{2}$ & 0,187 & 0,188 & 0,301 & 0,303 & 0,208 & 0,208 \\
\hline$R^{2}$ Ajustado & 0,187 & 0,187 & 0,290 & 0,292 & 0,208 & 0,208 \\
\hline
\end{tabular}

Fonte: Resultados da pesquisa.

Elaboração dos autores.

Obs.: 1. $M P=$ micro e pequenas empresas; $M G=$ médias e grandes empresas; $A L L=$ todas as empresas; $C P=$ curto prazo, igual a 1 para 0 ano de tratamento; $\mathrm{LP}=$ longo prazo, igual a 1 para os anos após o tratamento.

2. ${ }^{*} p<0.10 ;{ }^{* *} p<0.05 ;{ }^{* *} p<0.01$.

3. (-) omitido devido à colinearidade. 
TABELA A.6

Impacto sobre a massa salarial no setor secundário

\begin{tabular}{|c|c|c|c|c|c|c|}
\hline Variáveis & $\mathrm{MP} / \mathrm{CP}$ & MP/LP & $M G / C P$ & $M G / L P$ & ALL/CP & ALL/LP \\
\hline Ano de acesso (giro e custeio) & $0,216^{* * *}$ & & $0,132^{* *}$ & & $0,191^{* * *}$ & \\
\hline Ano de acesso (investimento) & $0,0525^{*}$ & & $0,0895^{* *}$ & & $0,0743^{* * *}$ & \\
\hline Anos após acesso (giro e custeio) & & $0,241^{* * *}$ & & $-0,0266$ & & $0,179^{* * *}$ \\
\hline Anos após acesso (investimento) & & $0,350 * * *$ & & 0,0886 & & $0,318^{* * *}$ \\
\hline PIB per capita & $0,00690^{* * *}$ & $0,00681^{* * *}$ & 0,00614 & 0,00607 & $0,00722^{* \star *}$ & $0,00711 * * *$ \\
\hline Tocantins & $-0,399$ & $-0,396$ & $0,202^{* * *}$ & $0,197^{* * *}$ & $-0,317$ & $-0,321$ \\
\hline Roraima & $-1,151$ & $-1,155$ & - & - & $-0,694$ & $-0,705$ \\
\hline Rondônia & $-1,732$ & $-1,733$ & $0,497^{* * *}$ & $0,494^{* * *}$ & $-1,271$ & $-1,279$ \\
\hline Amapá & $-0,689$ & $-0,728$ & - & - & $-0,724$ & $-0,757$ \\
\hline Amazonas & $-1,321$ & $-1,317$ & - & - & $-0,861$ & $-0,864$ \\
\hline Acre & - & - & - & - & - & - \\
\hline Proporção de funcionários analfabetos & $-0,0174^{* * *}$ & $-0,0176^{* * *}$ & $0,0986^{* * *}$ & $0,0945^{* * *}$ & $-0,0166^{* * *}$ & $-0,0166^{* * *}$ \\
\hline Proporção com fundamental incompleto & $-0,0168^{* * *}$ & $-0,0170^{* * *}$ & $0,0965^{* * *}$ & $0,0926 * * *$ & $-0,0161^{* * *}$ & $-0,0160^{* * *}$ \\
\hline Proporção com fundamental completo & $-0,0167^{* * *}$ & $-0,0169 * * *$ & $0,0976^{* * *}$ & $0,0936 * * *$ & $-0,0159^{* * *}$ & $-0,0158 * * *$ \\
\hline Proporção com ensino médio & $-0,0166^{* * *}$ & $-0,0168^{* * *}$ & $0,102^{* * *}$ & $0,0984^{* * *}$ & $-0,0159^{\star *}$ & $-0,0158^{* * *}$ \\
\hline Proporção com ensino superior & $-0,0175^{* * *}$ & $-0,0176^{\star * *}$ & $0,0981^{* * *}$ & $0,0941 * * *$ & $-0,0180^{* * *}$ & $-0,0179^{* * *}$ \\
\hline Proporção com pós-graduação & $-0,0145^{* *}$ & $-0,0146^{* *}$ & $-0,0446$ & $-0,0538$ & $-0,0146^{* *}$ & $-0,0147^{* *}$ \\
\hline Tendência linear & $0,0490 * * *$ & $0,0462^{* * *}$ & $0,0734^{* * *}$ & $0,0721 * * *$ & $0,0466^{* * *}$ & $0,0438^{* * *}$ \\
\hline 2000 (ano) & - & - & - & - & - & - \\
\hline 2001 (ano) & $-0,0406^{* * *}$ & $-0,0409 * * *$ & $-0,0893^{* * *}$ & $-0,0880 * * *$ & $-0,0428^{* * *}$ & $-0,0435^{\star * *}$ \\
\hline 2002 (ano) & $-0,123^{* * *}$ & $-0,122^{\star * \star}$ & $-0,156^{* \star *}$ & $-0,154^{* * *}$ & $-0,125^{* * *}$ & $-0,125^{* * *}$ \\
\hline 2003 (ano) & $-0,127^{* * *}$ & $-0,126^{* * *}$ & $-0,115^{* * *}$ & $-0,114^{\star * *}$ & $-0,125^{* * *}$ & $-0,125^{* * *}$ \\
\hline 2004 (ano) & $-0,105^{* * *}$ & $-0,104^{* * *}$ & $-0,0993^{* * *}$ & $-0,0986^{* * *}$ & $-0,107^{* * *}$ & $-0,106^{* * *}$ \\
\hline 2005 (ano) & $-0,0922^{* * *}$ & $-0,0907^{* * *}$ & $-0,0743^{* * *}$ & $-0,0771^{* * *}$ & $-0,0946^{* * *}$ & $-0,0940^{* * *}$ \\
\hline 2006 (ano) & $-0,0520^{* * *}$ & $-0,0501^{* * *}$ & $-0,0316$ & $-0,0338$ & $-0,0562^{* * *}$ & $-0,0551^{* * *}$ \\
\hline 2007 (ano) & $-0,0476^{* * *}$ & $-0,0455^{* * *}$ & 0,00766 & 0,00568 & $-0,0466^{\star \star *}$ & $-0,0452^{* * *}$ \\
\hline 2008 (ano) & $-0,0767^{* * *}$ & $-0,0746^{\star * *}$ & $-0,0317$ & $-0,0319$ & $-0,0723^{* \star *}$ & $-0,0709^{* * *}$ \\
\hline 2009 (ano) & $-0,0600 * * *$ & $-0,0585^{* * *}$ & $-0,0383^{* *}$ & $-0,0365^{\star *}$ & $-0,0563^{* * *}$ & $-0,0552^{* * *}$ \\
\hline 2010 (ano) & - & - & - & - & - & - \\
\hline Micro ou pequena empresa & & & & & $-2,219 * * *$ & $-2,192^{* * *}$ \\
\hline Média empresa & & & & & $-0,843^{* * *}$ & $-0,821 * * *$ \\
\hline Grande empresa & & & & & - & - \\
\hline Constante & $-87,72^{* * *}$ & $-82,00^{* * *}$ & $-144,7^{* \star *}$ & $-141,8^{* * *}$ & $-80,68^{* * *}$ & $-75,11^{\text {*** }}$ \\
\hline Observações & 66.845 & 66.845 & 3.827 & 3.827 & 70.672 & 70.672 \\
\hline$R^{2}$ & 0,051 & 0,054 & 0,364 & 0,363 & 0,117 & 0,119 \\
\hline$R^{2}$ Ajustado & 0,051 & 0,054 & 0,360 & 0,359 & 0,117 & 0,119 \\
\hline
\end{tabular}

Fonte: Resultados da pesquisa.

Elaboração dos autores.

Obs.: 1. MP = micro e pequenas empresas; $M G=$ médias e grandes empresas; $A L L=$ todas as empresas; $C P=$ curto prazo, igual a 1 para 0 ano de tratamento; $\mathrm{LP}=$ longo prazo, igual a 1 para os anos após 0 tratamento.

2. ${ }^{*} p<0.10 ;{ }^{* *} p<0.05 ;{ }^{* * *} p<0.01$.

3. (-) omitido devido à colinearidade. 
TABELA A.7

Impacto sobre a massa salarial no setor terciário

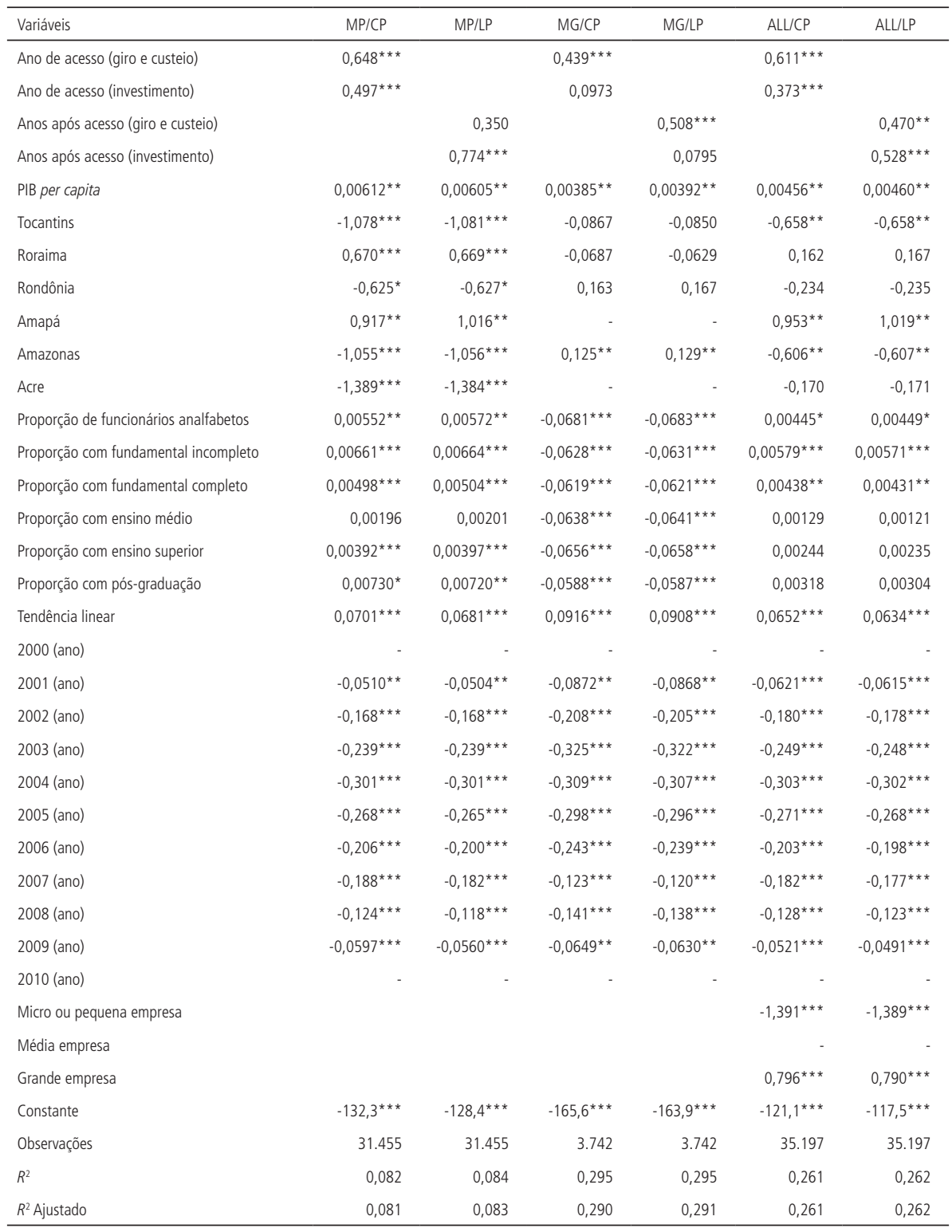

Fonte: Resultados da pesquisa.

Elaboração dos autores.

Obs.: 1. MP = micro e pequenas empresas; $M G=$ médias e grandes empresas; $A L L=$ todas as empresas; $C P=$ curto prazo, igual a 1 para 0 ano de tratamento; $L P=$ longo prazo, igual a 1 para os anos após o tratamento.

2. ${ }^{*} p<0.10 ;{ }^{* *} p<0.05 ;{ }^{* * *} p<0.01$.

3. (-) omitido devido à colinearidade. 
TABELA A.8

Impacto sobre a massa salarial na economia da região Norte

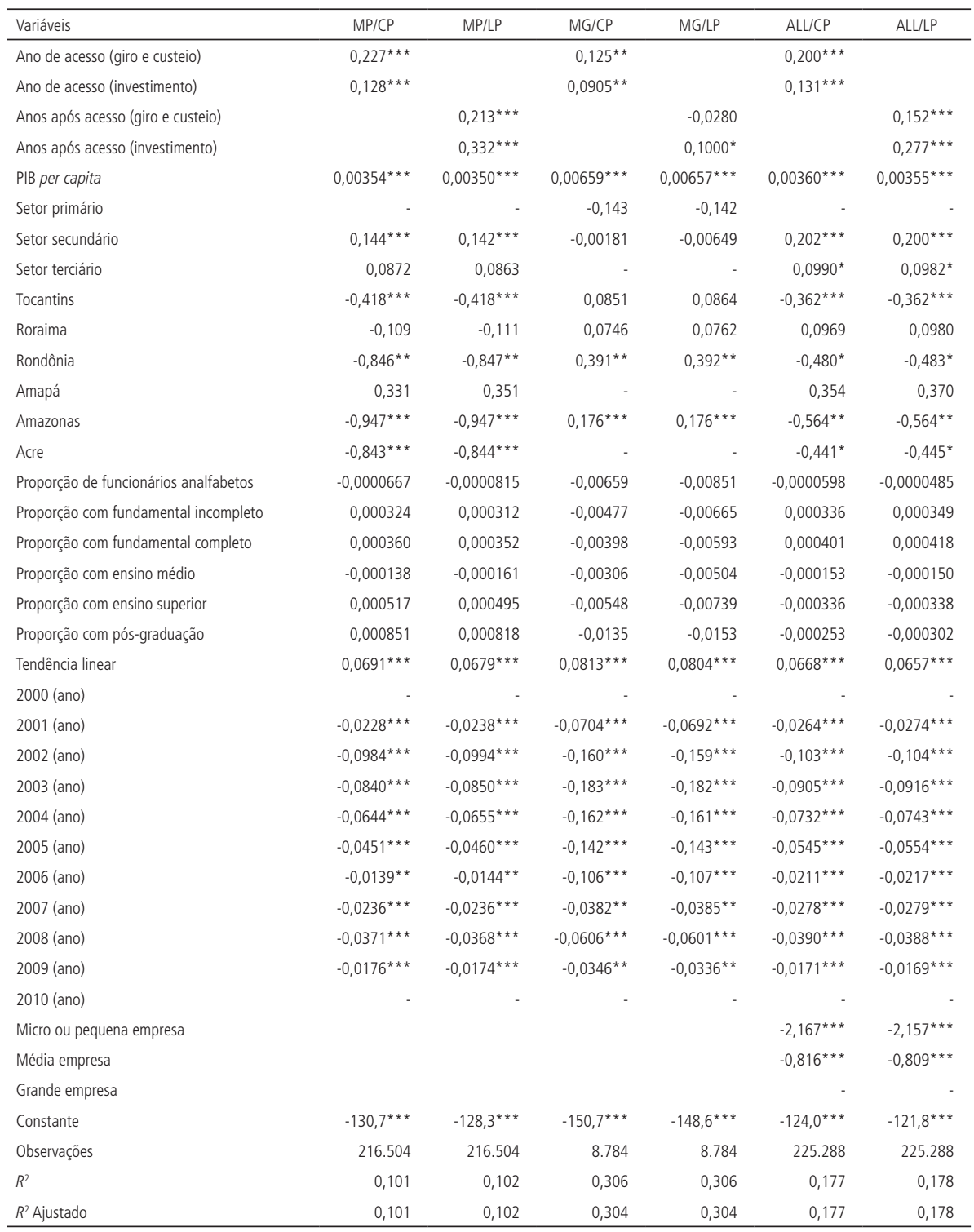

Fonte: Resultados da pesquisa.

Elaboração dos autores.

Obs.: 1. MP = micro e pequenas empresas; $M G=$ médias e grandes empresas; $A L L=$ todas as empresas; $C P=$ curto prazo, igual a 1 para 0 ano de tratamento; $L P=$ longo prazo, igual a 1 para os anos após o tratamento.

2. ${ }^{*} p<0.10 ;{ }^{* *} p<0.05 ;{ }^{* * *} p<0.01$.

3. (-) omitido devido à colinearidade. 
TABELA A.9

Impacto sobre o salário médio no setor primário

\begin{tabular}{|c|c|c|c|c|c|c|}
\hline Variáveis & $\mathrm{MP} / \mathrm{CP}$ & $M P / L P$ & $\mathrm{MG} / \mathrm{CP}$ & MG/LP & ALL/CP & ALL/LP \\
\hline Ano de acesso (giro e custeio) & 0,00723 & & 0,0339 & & 0,00779 & \\
\hline Ano de acesso (investimento) & 0,0000960 & & 0,0199 & & 0,0104 & \\
\hline Anos após acesso (giro e custeio) & & $-0,0291$ & & 0,0241 & & $-0,0290$ \\
\hline Anos após acesso (investimento) & & $-0,0267$ & & 0,101 & & $-0,00490$ \\
\hline PIB per capita & 0,000425 & 0,000424 & $0,00437 * * *$ & $0,00433^{* * *}$ & 0,000517 & 0,000515 \\
\hline Tocantins & $-0,0414$ & $-0,0413$ & - & - & $-0,0418$ & $-0,0417$ \\
\hline Roraima & - & - & - & - & - & - \\
\hline Rondônia & $0,112^{* * *}$ & $0,112^{* * *}$ & - & - & $0,110^{* * *}$ & $0,110^{* * *}$ \\
\hline Amapá & 0,0420 & 0,0419 & - & - & 0,0430 & 0,0430 \\
\hline Amazonas & - & - & - & - & - & - \\
\hline Acre & $0,0630^{*}$ & $0,0630^{*}$ & - & - & $0,0602^{*}$ & $0,0603^{*}$ \\
\hline Proporção de funcionários analfabetos & $-0,000261$ & $-0,000260$ & $-0,0814^{*}$ & $-0,0838^{*}$ & $-0,000302^{*}$ & $-0,000301$ * \\
\hline Proporção com fundamental incompleto & 0,0000289 & 0,0000299 & $-0,0807^{\star}$ & $-0,0832^{*}$ & $-0,0000115$ & $-0,0000109$ \\
\hline Proporção com fundamental completo & 0,000138 & 0,000139 & $-0,0812^{*}$ & $-0,0838^{*}$ & 0,0000996 & 0,000100 \\
\hline Proporção com ensino médio & $0,000551 * * *$ & $0,000552^{* * *}$ & $-0,0792^{*}$ & $-0,0817^{*}$ & $0,000528^{* * *}$ & $0,000529 * * *$ \\
\hline Proporção com ensino superior & $0,00516^{* * *}$ & $0,00517^{* * *}$ & $-0,0707$ & $-0,0732$ & $0,00538^{* * *}$ & $0,00539^{* * *}$ \\
\hline Proporção com pós-graduação & $-0,000877$ & $-0,000877$ & $-0,0759^{* * *}$ & $-0,0775^{* * *}$ & $-0,000879$ & $-0,000878$ \\
\hline Tendência linear & $0,0564 * * *$ & $0,0564^{* * *}$ & $0,0407^{* * *}$ & $0,0403^{* * *}$ & $0,0561 * * *$ & $0,0561 * * *$ \\
\hline 2000 (ano) & - & - & - & - & - & - \\
\hline 2001 (ano) & 0,00431 & 0,00433 & $-0,0152$ & $-0,0132$ & 0,00435 & 0,00435 \\
\hline 2002 (ano) & $-0,0724^{* * *}$ & $-0,0723^{* * *}$ & $-0,135^{* * *}$ & $-0,134^{* * *}$ & $-0,0733^{* * *}$ & $-0,0733^{* * *}$ \\
\hline 2003 (ano) & $-0,0537^{* * *}$ & $-0,0537^{* * *}$ & $-0,117^{* * *}$ & $-0,115^{* * *}$ & $-0,0549 * * *$ & $-0,0549^{* * *}$ \\
\hline 2004 (ano) & $-0,0742^{* * *}$ & $-0,0741^{* * *}$ & $-0,106^{* * *}$ & $-0,105^{* * *}$ & $-0,0747^{* * *}$ & $-0,0747^{\star * *}$ \\
\hline 2005 (ano) & $-0,0321 * * *$ & $-0,0320^{* * *}$ & $-0,0865^{* * *}$ & $-0,0854^{* * *}$ & $-0,0329 * * *$ & $-0,0329^{* * *}$ \\
\hline 2006 (ano) & $0,0151 * * *$ & $0,0151^{* * *}$ & $-0,0320$ & $-0,0303$ & $0,0141^{\star * *}$ & $0,0141 * * *$ \\
\hline 2007 (ano) & $-0,00419$ & $-0,00416$ & $-0,0359^{*}$ & $-0,0340^{*}$ & $-0,00489^{*}$ & $-0,00490^{*}$ \\
\hline 2008 (ano) & $-0,0122^{\star * *}$ & $-0,0121^{* \star *}$ & $-0,0278$ & $-0,0279$ & $-0,0126^{* * *}$ & $-0,0125^{* * *}$ \\
\hline 2009 (ano) & $0,00901^{* * *}$ & $0,00902^{* * *}$ & 0,00330 & 0,00354 & $0,00868^{* * *}$ & $0,00867^{* * *}$ \\
\hline 2010 (ano) & - & - & - & - & - & - \\
\hline Micro ou pequena empresa & & & & & - & - \\
\hline Média empresa & & & & & $-0,0647^{* * *}$ & $-0,0648^{* * *}$ \\
\hline Grande empresa & & & & & $-0,0752^{\star *}$ & $-0,0742^{* *}$ \\
\hline Constante & $-106,8^{* \star *}$ & $-106,9^{* * *}$ & $-66,78^{* * *}$ & $-65,75^{* * *}$ & $-106,3^{* * *}$ & $-106,3^{* * *}$ \\
\hline Observações & 118.204 & 118.204 & 1.215 & 1.215 & 119.419 & 119.419 \\
\hline$R^{2}$ & 0,402 & 0,402 & 0,471 & 0,472 & 0,401 & 0,401 \\
\hline$R^{2}$ Ajustado & 0,402 & 0,402 & 0,462 & 0,464 & 0,401 & 0,401 \\
\hline
\end{tabular}

Fonte: Resultados da pesquisa.

Elaboração dos autores.

Obs.: 1. MP = micro e pequenas empresas; $M G=$ médias e grandes empresas; $A L L=$ todas as empresas; $C P=$ curto prazo, igual a 1 para 0 ano de tratamento; $\mathrm{LP}=$ longo prazo, igual a 1 para os anos após 0 tratamento.

2. ${ }^{*} p<0.10 ;{ }^{* *} p<0.05 ;{ }^{* * *} p<0.01$.

3. (-) omitido devido à colinearidade. 
TABELA A. 10

Impacto sobre o salário médio no setor secundário

\begin{tabular}{|c|c|c|c|c|c|c|}
\hline Variáveis & $\mathrm{MP} / \mathrm{CP}$ & MP/LP & $\mathrm{MG} / \mathrm{CP}$ & $M G / L P$ & $\mathrm{ALL} / \mathrm{CP}$ & ALL/LP \\
\hline Ano de acesso (giro e custeio) & 0,00640 & & $-0,00761$ & & 0,0155 & \\
\hline Ano de acesso (investimento) & 0,00177 & & 0,00529 & & 0,00277 & \\
\hline Anos após acesso (giro e custeio) & & $0,0433^{* *}$ & & 0,0205 & & $0,0344^{*}$ \\
\hline Anos após acesso (investimento) & & 0,0224 & & $0,0522^{* *}$ & & $0,0215^{*}$ \\
\hline PIB per capita & $-0,000129$ & $-0,000132$ & $-0,00174$ & $-0,00169$ & $-0,000368$ & $-0,000374$ \\
\hline Tocantins & $-0,146$ & $-0,145$ & $-0,515^{* * *}$ & $-0,520 * * *$ & $-0,280^{* *}$ & $-0,280^{* *}$ \\
\hline Roraima & $-0,0739$ & $-0,0740$ & - & - & $-0,0589$ & $-0,0598$ \\
\hline Rondônia & $-0,327$ & $-0,327$ & $-0,571^{* * *}$ & $-0,580^{\star \star *}$ & $-0,309$ & $-0,309$ \\
\hline Amapá & 0,0756 & 0,0730 & - & - & 0,0818 & 0,0793 \\
\hline Amazonas & $-0,501^{*}$ & $-0,500^{*}$ & - & - & $-0,479 * *$ & $-0,479^{* *}$ \\
\hline Acre & - & - & - & - & - & - \\
\hline Proporção de funcionários analfabetos & $-0,0169^{* * *}$ & $-0,0170^{* * *}$ & $-0,0210$ & $-0,0207$ & $-0,0166^{* * *}$ & $-0,0166^{* * *}$ \\
\hline Proporção com fundamental incompleto & $-0,0161^{* * *}$ & $-0,0161^{* * *}$ & $-0,0236$ & $-0,0234$ & $-0,0158^{* * *}$ & $-0,0158^{* * *}$ \\
\hline Proporção com fundamental completo & $-0,0158^{* * *}$ & $-0,0158^{* * *}$ & $-0,0207$ & $-0,0204$ & $-0,0155^{* * *}$ & $-0,0155^{* * *}$ \\
\hline Proporção com ensino médio & $-0,0152^{* * *}$ & $-0,0152^{* * *}$ & $-0,0216$ & $-0,0213$ & $-0,0149^{* * *}$ & $-0,0149^{* * *}$ \\
\hline Proporção com ensino superior & $-0,00984^{* *}$ & $-0,00984^{* *}$ & $-0,0186$ & $-0,0183$ & $-0,00916^{* *}$ & $-0,00915^{\star *}$ \\
\hline Proporção com pós-graduação & $-0,0118^{* * *}$ & $-0,0118^{* * *}$ & $-0,0569^{* *}$ & $-0,0570^{* *}$ & $-0,0116^{* * *}$ & $-0,0116^{* * *}$ \\
\hline Tendência linear & $0,0478^{* * *}$ & $0,0475^{* * *}$ & $0,0311^{* * *}$ & $0,0301^{* * *}$ & $0,0466^{\star * *}$ & $0,0464^{* * *}$ \\
\hline 2000 (ano) & - & - & - & - & - & - \\
\hline 2001 (ano) & $-0,0177^{* * *}$ & $-0,0176^{* * *}$ & $-0,0154$ & $-0,0162$ & $-0,0172^{\star * *}$ & $-0,0172^{* * *}$ \\
\hline 2002 (ano) & $-0,105^{* * *}$ & $-0,105^{* * *}$ & $-0,107^{* * *}$ & $-0,108^{* * *}$ & $-0,104^{* * *}$ & $-0,104^{* * *}$ \\
\hline 2003 (ano) & $-0,0850^{* * *}$ & $-0,0848^{* * *}$ & $-0,0842^{* * *}$ & $-0,0857^{* * *}$ & $-0,0840 * * *$ & $-0,0839 * * *$ \\
\hline 2004 (ano) & $-0,0977^{* * *}$ & $-0,0975^{* * *}$ & $-0,109^{* * *}$ & $-0,111^{* * *}$ & $-0,0970^{* * *}$ & $-0,0969 * * *$ \\
\hline 2005 (ano) & $-0,0649^{* * *}$ & $-0,0646^{* * *}$ & $-0,0707^{* * *}$ & $-0,0710^{* * *}$ & $-0,0654^{* * *}$ & $-0,0652^{* * *}$ \\
\hline 2006 (ano) & $-0,0208^{* * *}$ & $-0,0204^{* * *}$ & $-0,0604^{* * *}$ & $-0,0602^{* * *}$ & $-0,0228^{* * *}$ & $-0,0225^{* * *}$ \\
\hline 2007 (ano) & $-0,0334^{* * *}$ & $-0,0329 * * *$ & $-0,0428^{* * *}$ & $-0,0426^{* * *}$ & $-0,0333^{* * *}$ & $-0,0329^{* * *}$ \\
\hline 2008 (ano) & $-0,0295^{* * *}$ & $-0,0290^{* * *}$ & $-0,0218^{* *}$ & $-0,0215^{* *}$ & $-0,0286^{\star \star *}$ & $-0,0283^{* * *}$ \\
\hline 2009 (ano) & $-0,00417$ & $-0,00390$ & 0,00437 & 0,00403 & $-0,00342$ & $-0,00322$ \\
\hline 2010 (ano) & - & - & - & - & - & \\
\hline Micro ou pequena empresa & & & & & $0,108^{* * *}$ & $0,110^{* * *}$ \\
\hline Média empresa & & & & & $0,0915^{* * *}$ & $0,0936^{\star * *}$ \\
\hline Grande empresa & & & & & - & - \\
\hline Constante & $-87,67^{* * *}$ & $-87,14^{* * *}$ & $-53,18^{* * *}$ & $-51,09 * * *$ & $-85,49^{* * *}$ & $-84,97^{* * *}$ \\
\hline Observações & 66.845 & 66.845 & 3.827 & 3.827 & 70.672 & 70.672 \\
\hline$R^{2}$ & 0,293 & 0,293 & 0,260 & 0,262 & 0,290 & 0,290 \\
\hline$R^{2}$ Ajustado & 0,293 & 0,293 & 0,256 & 0,257 & 0,290 & 0,290 \\
\hline
\end{tabular}

Fonte: Resultados da pesquisa.

Elaboração dos autores.

Obs.: 1. $M P=$ micro e pequenas empresas; $M G=$ médias e grandes empresas; $A L L=$ todas as empresas; $C P=$ curto prazo, igual a 1 para 0 ano de tratamento; $\mathrm{LP}=$ longo prazo, igual a 1 para os anos após 0 tratamento.

2. ${ }^{*} p<0.10 ;{ }^{* *} p<0.05 ;{ }^{* *} p<0.01$.

3. (-) omitido devido à colinearidade. 


\section{TABELA A. 11 \\ Impacto sobre o salário médio no setor terciário}

\begin{tabular}{|c|c|c|c|c|c|c|}
\hline Variáveis & $\mathrm{MP} / \mathrm{CP}$ & MP/LP & $\mathrm{MG} / \mathrm{CP}$ & $M G / L P$ & $\mathrm{ALL} / \mathrm{CP}$ & ALL/LP \\
\hline Ano de acesso (giro e custeio) & 0,0229 & & 0,0616 & & 0,0452 & \\
\hline Ano de acesso (investimento) & 0,0289 & & $-0,102$ & & 0,00435 & \\
\hline Anos após acesso (giro e custeio) & & 0,0411 & & 0,0923 & & $0,0713^{*}$ \\
\hline Anos após acesso (investimento) & & $0,0908 * * *$ & & $-0,0925$ & & 0,0471 \\
\hline PIB per capita & $-0,000123$ & $-0,000141$ & $-0,000205$ & $-0,000244$ & $-0,000286$ & $-0,000288$ \\
\hline Tocantins & $-0,0503$ & $-0,0507$ & $-0,105^{* * *}$ & $-0,106^{* * *}$ & $-0,114$ & $-0,114$ \\
\hline Roraima & $-0,149^{* * *}$ & $-0,149^{* * *}$ & $-0,301^{* * *}$ & $-0,303^{* * *}$ & $-0,204^{* *}$ & $-0,204^{* *}$ \\
\hline Rondônia & $-0,108$ & $-0,108$ & $-0,0199$ & $-0,0223$ & $-0,119$ & $-0,119$ \\
\hline Amapá & 0,0838 & $0,0975^{*}$ & - & - & $0,117^{* *}$ & $0,125^{* * *}$ \\
\hline Amazonas & $-0,111$ & $-0,111$ & $-0,300^{* * *}$ & $-0,301 * * *$ & $-0,123$ & $-0,123$ \\
\hline Acre & $-0,224^{*}$ & $-0,223^{*}$ & - & - & 0,148 & 0,148 \\
\hline Proporção de funcionários analfabetos & $-0,00557^{* * *}$ & $-0,00555^{* * *}$ & $-0,00179$ & $-0,00142$ & $-0,00560^{* * *}$ & $-0,00557^{* * *}$ \\
\hline Proporção com fundamental incompleto & $-0,00491^{* * *}$ & $-0,00491^{* * *}$ & $-0,000487$ & $-0,000140$ & $-0,00489^{* * *}$ & $-0,00488^{* * *}$ \\
\hline Proporção com fundamental completo & $-0,00504^{* * *}$ & $-0,00504^{* * *}$ & $-0,00151$ & $-0,00117$ & $-0,00498^{* * *}$ & $-0,00496^{* * *}$ \\
\hline Proporção com ensino médio & $-0,00419 * * *$ & $-0,00418^{* * *}$ & 0,00123 & 0,00160 & $-0,00400^{* * *}$ & $-0,00399 * * *$ \\
\hline Proporção com ensino superior & $0,00311^{* * *}$ & $0,00312^{* * *}$ & 0,0109 & 0,0112 & $0,00361^{* * *}$ & $0,00363^{* * *}$ \\
\hline Proporção com pós-graduação & 0,00229 & 0,00230 & 0,0113 & 0,0115 & 0,00209 & 0,00213 \\
\hline Tendência linear & $0,0396 * * *$ & $0,0393^{* * *}$ & $0,0405^{* * *}$ & $0,0411^{* * *}$ & $0,0383^{* * *}$ & $0,0381 * * *$ \\
\hline 2000 (ano) & - & - & - & - & - & - \\
\hline 2001 (ano) & $-0,0719^{* * *}$ & $-0,0718^{* * *}$ & $-0,0473^{* * *}$ & $-0,0477^{* * *}$ & $-0,0696^{* * *}$ & $-0,0695^{* * *}$ \\
\hline 2002 (ano) & $-0,138^{* * *}$ & $-0,138^{* * *}$ & $-0,0893^{* * *}$ & $-0,0908^{* * *}$ & $-0,135^{* * *}$ & $-0,135^{* * *}$ \\
\hline 2003 (ano) & $-0,136 * * *$ & $-0,136^{* * *}$ & $-0,118^{* * *}$ & $-0,119 * * *$ & $-0,135^{* * *}$ & $-0,135^{\star * *}$ \\
\hline 2004 (ano) & $-0,144^{* * *}$ & $-0,144^{* * *}$ & $-0,145^{* * *}$ & $-0,146^{\star * *}$ & $-0,142^{* * *}$ & $-0,142^{* * *}$ \\
\hline 2005 (ano) & $-0,125^{* * *}$ & $-0,124^{* * *}$ & $-0,133^{* * *}$ & $-0,134^{* * *}$ & $-0,124^{* * *}$ & $-0,124^{* * *}$ \\
\hline 2006 (ano) & $-0,102^{* * *}$ & $-0,101^{* * *}$ & $-0,126$ *** & $-0,129 * * *$ & $-0,100 * * *$ & $-0,0996 * * *$ \\
\hline 2007 (ano) & $-0,0960^{* * *}$ & $-0,0952^{* * *}$ & $-0,112^{* * *}$ & $-0,115^{* * *}$ & $-0,0983^{* * *}$ & $-0,0976^{* * *}$ \\
\hline 2008 (ano) & $-0,0738^{* * *}$ & $-0,0731^{* * *}$ & $-0,0806 * * *$ & $-0,0820$ *** & $-0,0721^{* * *}$ & $-0,0716^{* * *}$ \\
\hline 2009 (ano) & $-0,0372^{* * *}$ & $-0,0369^{* * *}$ & $-0,0402^{* * *}$ & $-0,0418^{* * *}$ & $-0,0332^{* * *}$ & $-0,0330^{\text {*** }}$ \\
\hline 2010 (ano) & - & - & - & - & - & - \\
\hline Micro ou pequena empresa & & & & & $-0,0351^{* * *}$ & $-0,0348^{* * *}$ \\
\hline Média empresa & & & & & - & - \\
\hline Grande empresa & & & & & 0,0110 & 0,0103 \\
\hline Constante & $-72,17^{* * *}$ & $-71,66^{* * *}$ & $-74,23^{\star * *}$ & $-75,46^{* * *}$ & $-69,53^{* * *}$ & $-69,17^{* * *}$ \\
\hline Observações & 31.455 & 31.455 & 3.742 & 3.742 & 35.197 & 35.197 \\
\hline$R^{2}$ & 0,223 & 0,224 & 0,337 & 0,337 & 0,229 & 0,229 \\
\hline$R^{2}$ Ajustado & 0,223 & 0,223 & 0,333 & 0,333 & 0,228 & 0,229 \\
\hline
\end{tabular}

Fonte: Resultados da pesquisa.

Elaboração dos autores.

Obs.: 1. MP = micro e pequenas empresas; $M G=$ médias e grandes empresas; $\mathrm{ALL}=$ todas as empresas; $\mathrm{CP}=$ curto prazo, igual a 1 para 0 ano de tratamento; $\mathrm{LP}=$ longo prazo, igual a 1 para os anos após 0 tratamento.

2. ${ }^{*} p<0.10 ;{ }^{* *} p<0.05 ;{ }^{* *} p<0.01$.

3. (-) omitido devido à colinearidade. 
TABELA A. 12

Impacto sobre o salário médio na economia da região Norte

\begin{tabular}{|c|c|c|c|c|c|c|}
\hline Variáveis & $\mathrm{MP} / \mathrm{CP}$ & MP/LP & $\mathrm{MG} / \mathrm{CP}$ & $M G / L P$ & $\mathrm{ALL} / \mathrm{CP}$ & ALL/LP \\
\hline Ano de acesso (giro e custeio) & 0,00653 & & 0,00349 & & 0,0149 & \\
\hline Ano de acesso (investimento) & 0,00429 & & $-0,0209$ & & 0,00336 & \\
\hline Anos após acesso (giro e custeio) & & 0,0229 & & 0,000256 & & 0,0143 \\
\hline Anos após acesso (investimento) & & 0,0144 & & 0,00176 & & 0,00830 \\
\hline PIB per capita & 0,000257 & 0,000255 & 0,000346 & 0,000356 & 0,000147 & 0,000145 \\
\hline Setor primário & - & - & $-0,0118$ & $-0,0114$ & - & - \\
\hline Setor secundário & $-0,0101$ & $-0,0102$ & $-0,0180$ & $-0,0178$ & $-0,0107$ & $-0,0108$ \\
\hline Setor terciário & 0,0191 & 0,0191 & - & - & 0,0177 & 0,0177 \\
\hline Tocantins & $-0,0391$ & $-0,0392$ & $-0,260^{* * *}$ & $-0,260^{* * *}$ & $-0,0771^{*}$ & $-0,0771^{*}$ \\
\hline Roraima & 0,102 & 0,102 & $-0,284^{* * *}$ & $-0,284^{* * *}$ & $-0,0630$ & $-0,0629$ \\
\hline Rondônia & $-0,0663$ & $-0,0663$ & $-0,108$ & $-0,107$ & $-0,0559$ & $-0,0560$ \\
\hline Amapá & $0,0850^{\star * *}$ & $0,0859^{* *}$ & - & - & $0,102^{* * *}$ & $0,103^{\text {*** }}$ \\
\hline Amazonas & $-0,137$ & $-0,137$ & $-0,288^{* * *}$ & $-0,288^{* * *}$ & $-0,133$ & $-0,133$ \\
\hline Acre & $-0,124$ & $-0,124$ & - & - & $-0,0906$ & $-0,0908$ \\
\hline Proporção de funcionários analfabetos & $-0,00456$ & $-0,00456$ & $-0,0173^{*}$ & $-0,0169^{*}$ & $-0,00454^{*}$ & $-0,00454^{*}$ \\
\hline Proporção com fundamental incompleto & $-0,00420$ & $-0,00420$ & $-0,0175^{*}$ & $-0,0171^{*}$ & $-0,00418$ & $-0,00418$ \\
\hline Proporção com fundamental completo & $-0,00408$ & $-0,00408$ & $-0,0172^{*}$ & $-0,0168^{*}$ & $-0,00404$ & $-0,00404$ \\
\hline Proporção com ensino médio & $-0,00356$ & $-0,00356$ & $-0,0158^{*}$ & $-0,0154^{*}$ & $-0,00350$ & $-0,00350$ \\
\hline Proporção com ensino superior & 0,00242 & 0,00242 & $-0,0102$ & $-0,00980$ & 0,00282 & 0,00282 \\
\hline Proporção com pós-graduação & $-0,00202$ & $-0,00202$ & $-0,00920$ & $-0,00874$ & $-0,00205$ & $-0,00205$ \\
\hline Tendência linear & $0,0508^{* * *}$ & $0,0507^{* * *}$ & $0,0349^{* * *}$ & $0,0349^{\star * *}$ & $0,0498^{* * *}$ & $0,0498^{* * *}$ \\
\hline 2000 (ano) & - & - & - & - & - & - \\
\hline 2001 (ano) & $-0,0166^{* * *}$ & $-0,0167^{* * *}$ & $-0,0292^{* * *}$ & $-0,0293^{* * *}$ & $-0,0171^{\star * *}$ & $-0,0171^{* * *}$ \\
\hline 2002 (ano) & $-0,0969^{* * *}$ & $-0,0969^{* * *}$ & $-0,103^{* * *}$ & $-0,103^{* * *}$ & $-0,0976^{* * *}$ & $-0,0976^{* * *}$ \\
\hline 2003 (ano) & $-0,0804^{* * *}$ & $-0,0804^{* * *}$ & $-0,104^{* * *}$ & $-0,105^{* * *}$ & $-0,0819^{* * *}$ & $-0,0820^{* * *}$ \\
\hline 2004 (ano) & $-0,0959^{* * *}$ & $-0,0960^{* * *}$ & $-0,126^{* * *}$ & $-0,126^{* * *}$ & $-0,0973^{* * *}$ & $-0,0974^{* * *}$ \\
\hline 2005 (ano) & $-0,0585^{\star * *}$ & $-0,0585^{* * *}$ & $-0,0984^{* * *}$ & $-0,0982^{* * *}$ & $-0,0608^{* * *}$ & $-0,0609 * * *$ \\
\hline 2006 (ano) & $-0,0134^{* * *}$ & $-0,0134^{* * *}$ & $-0,0844^{* * *}$ & $-0,0844^{* * *}$ & $-0,0165^{* * *}$ & $-0,0165^{* * *}$ \\
\hline 2007 (ano) & $-0,0265^{\star * *}$ & $-0,0265^{* * *}$ & $-0,0714^{* * *}$ & $-0,0715^{* * *}$ & $-0,0290^{* * *}$ & $-0,0290^{* * *}$ \\
\hline 2008 (ano) & $-0,0265^{* * *}$ & $-0,0264^{* * *}$ & $-0,0492^{* * *}$ & $-0,0495^{* * *}$ & $-0,0274^{* * *}$ & $-0,0273^{* * *}$ \\
\hline 2009 (ano) & $-0,00148$ & $-0,00144$ & $-0,0153^{* * *}$ & $-0,0155^{* * *}$ & $-0,00167$ & $-0,00165$ \\
\hline 2010 (ano) & - & - & - & - & - & - \\
\hline Micro ou pequena empresa & & & & & 0,0151 & 0,0154 \\
\hline Média empresa & & & & & 0,0131 & 0,0134 \\
\hline Grande empresa & & & & & - & - \\
\hline Constante & $-95,10^{* * *}$ & $-94,97^{* * *}$ & $-61,27^{* * *}$ & $-61,29 * * *$ & $-93,09 * * *$ & $-93,00$ *** \\
\hline Observações & 216504 & 216504 & 8784 & 8784 & 225288 & 225288 \\
\hline$R^{2}$ & 0,334 & 0,334 & 0,299 & 0,299 & 0,329 & 0,329 \\
\hline$R^{2}$ Ajustado & 0,334 & 0,334 & 0,297 & 0,297 & 0,329 & 0,329 \\
\hline
\end{tabular}

Fonte: Resultados da pesquisa.

Elaboração dos autores.

Obs.: 1. MP = micro e pequenas empresas; $M G=$ médias e grandes empresas; $A L L=$ todas as empresas; $C P=$ curto prazo, igual a 1 para 0 ano de tratamento; LP = longo prazo, igual a 1 para os anos após 0 tratamento.

2. ${ }^{*} p<0.10 ;{ }^{* *} p<0.05 ;{ }^{* * *} p<0.01$.

3. (-) omitido devido à colinearidade. 


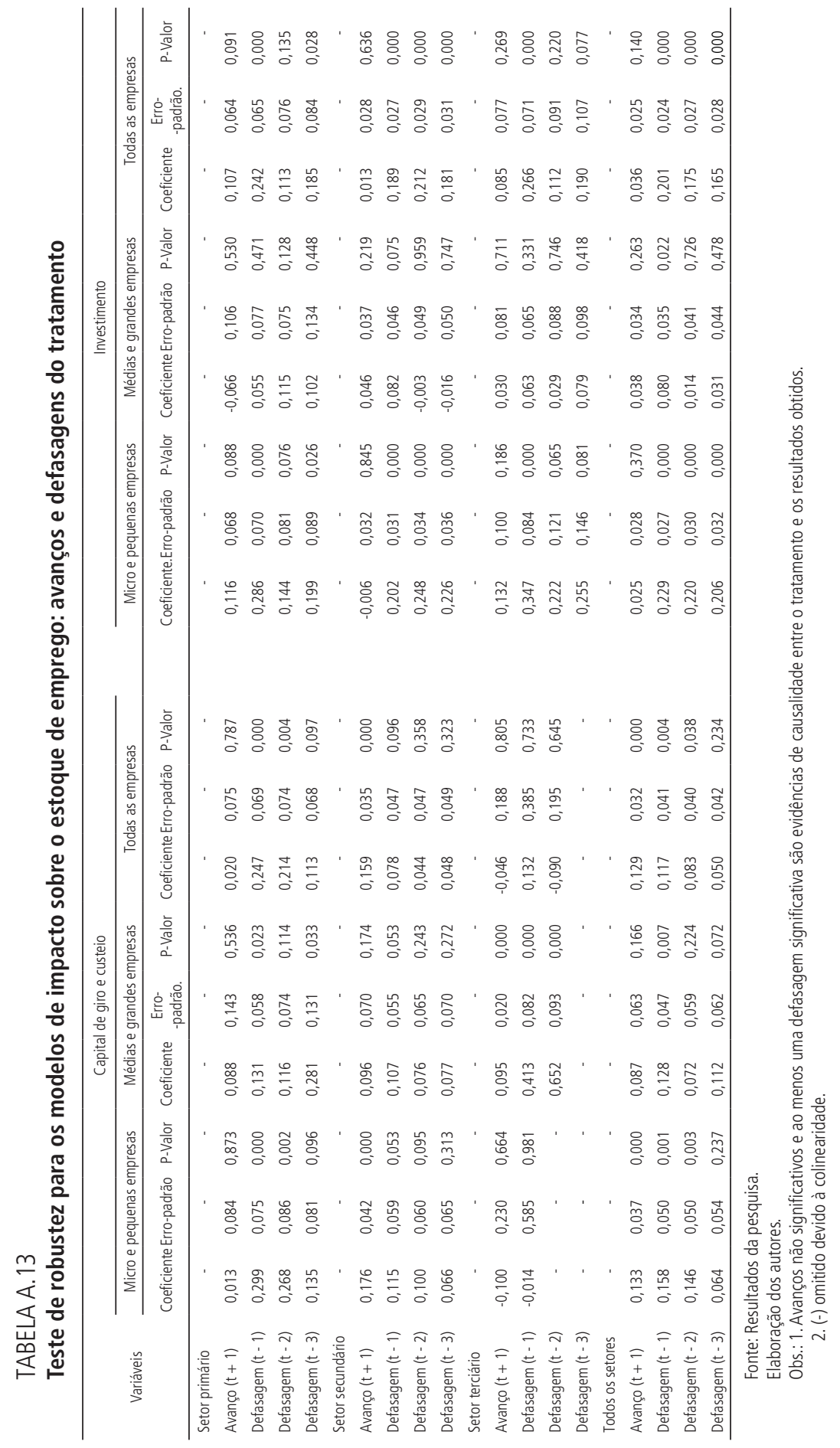




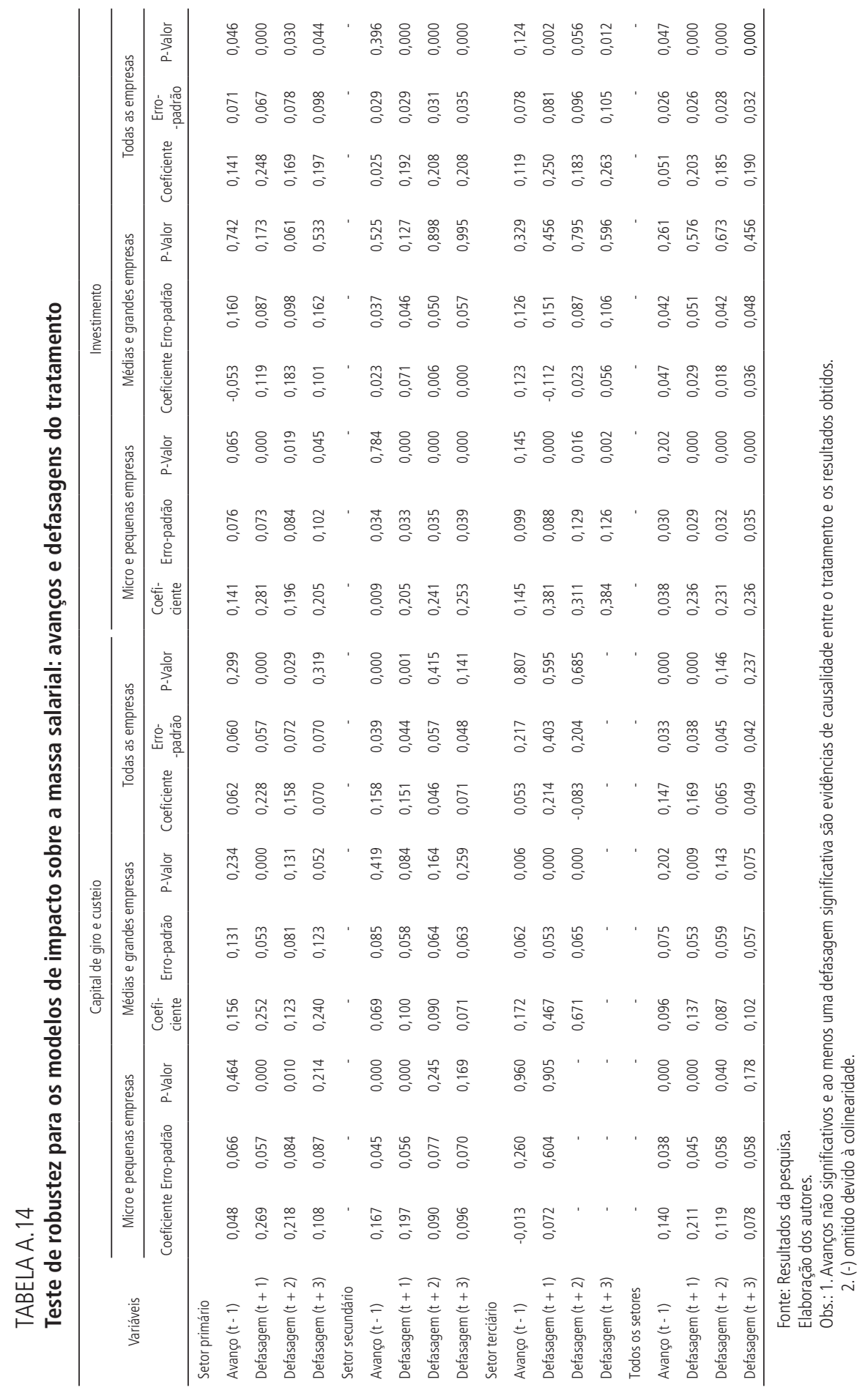




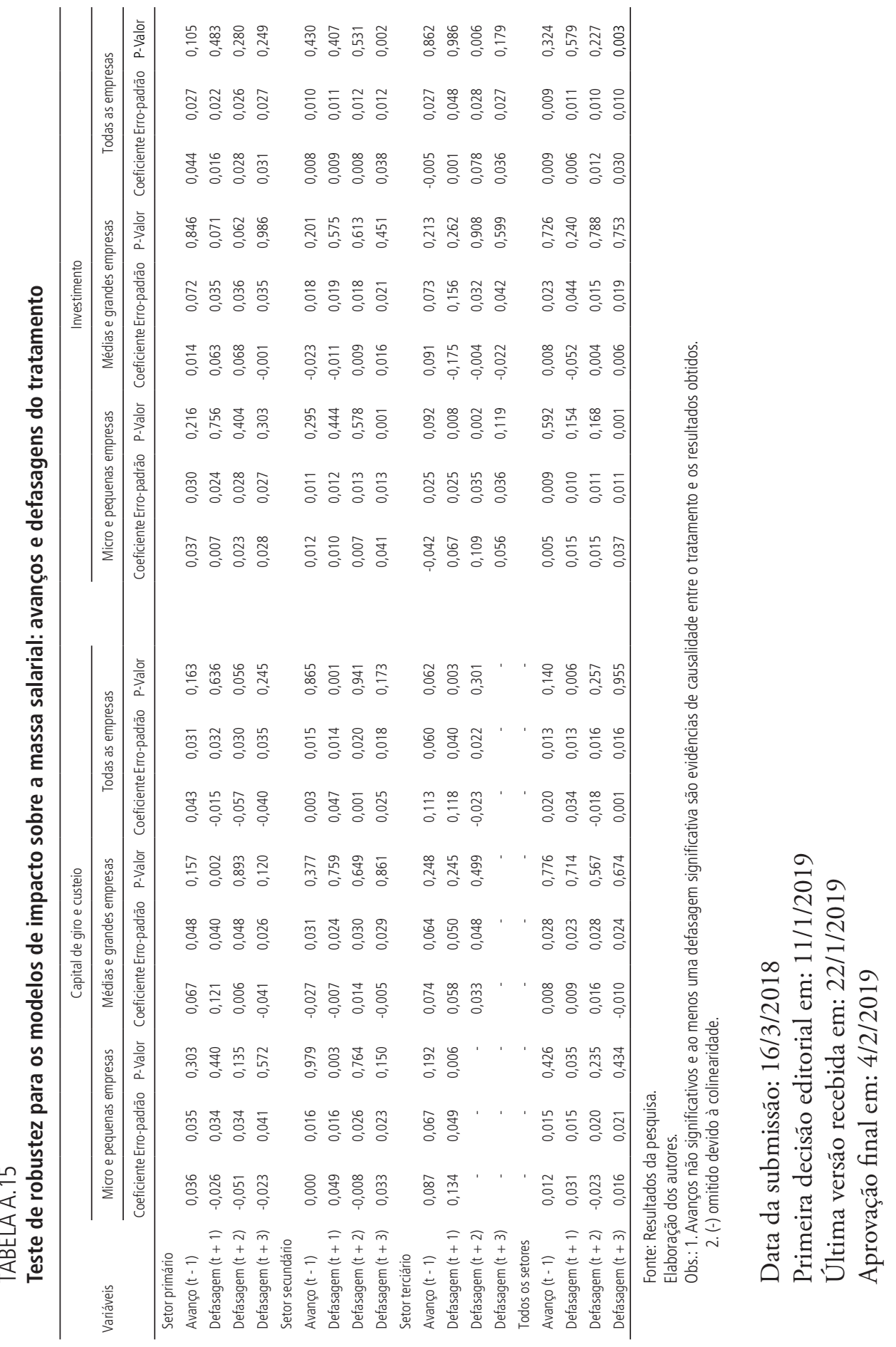

